Friend or Foe? Foreign investors and the liquidity of six Asian markets

\author{
Diego A. Agudelo **
}

* Associate Professor. Finance Department. EAFIT University, Medellin, Colombia. Kra. 497 Sur 50 of. $26-519$. dagudelo@eafit.edu.co. Office (574)2619500-9719. Mobile (54) 317 7347857. This is the second essay of my dissertation on the Finance $\mathrm{PhD}$ program at Indiana University. I'm greatly indebted to my advisor Craig Holden for his guidance and support. I also thank Utpal Bhattacharya, Sam Henkel, Pab Jotikastshira, Christian Lundblad, Chuck Trzcinka and participants at three Indiana University seminars for useful comments. I acknowledge the economic support of EAFIT University, Colombia and Indiana University CIBER. All remaining errors are mine. 


\title{
Friend or Foe? Foreign investors and the liquidity of six Asian markets
}

\begin{abstract}
Studying Foreign flows and the liquidity of six Asian markets we provide evidence of two empirical regularities: On the one hand, foreign trade has a negative but transitory impact on the overall liquidity of the market on a daily basis. This finding is shown consistent with two hypotheses: that foreign investors demand liquidity more aggressively than locals, and, to a lesser extent, that foreigners incorporate market-wide information. On the other hand, the overall share of foreign ownership in the market is positively related to improved liquidity, as shown in a sample of emerging markets, after controlling for a set of confounding factors. Overall, the results portray foreign investors as aggressive liquidity demanding, and nevertheless having a positive effect on the liquidity in short horizons.
\end{abstract}




\section{Introduction}

Liquidity is a critical factor to consider in emerging stock markets. From a practitioner's point of view, liquidity is a first order factor to evaluate investment opportunities in emerging markets: the substantial returns potentially earned can be substantially reduced after accounting for trading costs. Moreover, institutional investors still regard liquidity as one of the major obstacles to invest in emerging markets, along with poor disclosure standards and weak regulatory regimes, as reported by Bekaert and Harvey (2003) and Freeman and Bartels (2000). From an academic perspective, liquidity is a fundamental characteristic of stock market development. Stock market liquidity is linked to economic growth (Levine (2003)), higher liquidity allows firms to raise capital at a lower cost (Ellul and Pagano (2005)), and increases the incentives for financial analysts to acquire information (Hölmstrom and Tirole (1993)). Furthermore, Bekaert, Harvey and Lundblad (2005) report that liquidity is a priced factor of returns in emerging markets. Liquidity considerations are fundamental to study efficiency and informed trading and to evaluate momentum strategies. For all its importance, the liquidity of emerging markets has been little studied, mainly because of the lack of good quality data. As indicated by Lesmond (2005), availability of daily bid-and-ask quotes is limited, and only a few studies have been able to use transaction data ${ }^{1,2}$.

In this paper, we explore the relationship between foreign investors and the liquidity of emerging markets. We provide evidence of two empirical regularities: On the one hand, foreign trade is negatively related to the overall liquidity of the market, on a daily frequency, for three out of seven emerging markets. Although the effect is economically small, it is statistically significant. On the other hand, increases on the overall share of foreign ownership in the market are positively related to improved liquidity on two of the seven emerging markets. Overall, the results portray foreign investors as aggressive liquidity demanding, and nevertheless having a positive effect on the liquidity in short horizons.

The consequences of allowing foreign investors in emerging markets have been controversial since the liberalization processes took place. Krugman (1998) and Stiglitz (1999) expressed fears of excessive volatilities and inflation, increased boom and bust cycles and appreciation of exchange rates caused by the instability of the foreign investor's flows and holdings. Unlike foreign direct investment, which is widely regarded as beneficial, foreign portfolio flows are considered potentially damaging for emerging economies. Foreign portfolio investments, sometimes dubbed 'hot money', might flee from a developing country at the first sign of trouble during times of financial stress, further disrupting its capital markets. In particular, foreign flows have been accused of causing Contagion, the transmission of financial instability across emerging markets, during the crises in the second half of the 90's. Furthermore, some economists have called for increasing regulation on foreign flows to emerging markets (Rubin and Weisberg (2003), Ffrench-Davis and Griffith-Jones (2002), Ito and Portes

\footnotetext{
${ }^{1}$ Bonser-Neal et al (2005), Choe, Kho and Stulz (2005) and Ghysels and Cherkaoui(2003) study liquidity on the stock markets of Indonesia, Korea and Morroco, respectively, using transaction data.

${ }^{2}$ Some cross-country studies such as Domowitz, Glen and Madhavan(2001), Levine and Schmukler (2005) and Bortolotti et al (2004) have opted to use turnover as a proxy for liquidity. See Lesmond (2005) for a criticism of the use of turnover as a proxy for liquidity.
} 
(1998) and Eichengreen (1999)) $)^{3}$. Although most of the emerging markets identified by Standard and Poors (2004) currently have few or none direct barriers to the entry of foreign investors, still countries such as India, China, Colombia, India, Indonesia, the Philippines, Saudi Arabia, Taiwan and Thailand have either formal restrictions for foreign outflows or ceilings to foreign ownership.

Hence, the question of whether foreign investors are 'friend or foe' of the emerging markets is still relevant. Do they make the markets more efficient, liquid, transparent and dynamic? Or does their speculative behavior make markets more volatile, unstable, prone to external shocks and financial crises?.

Empirical answers have mostly focused on the effects of the liberalizations of emerging markets that took place in the late 80 's and early 90 's. Some of the results have been unambiguously positive: the evidence suggested that, upon liberalization, the incoming foreign speculators benefited the emerging markets: the cost of capital decreased, as reported by Miller (1999), Errunza and Miller (2000), Bekaert and Harvey (2000) and Henry (2000), and the efficiency of the markets increased, as reported by Kim and Singal (2000). There is also a positive association between the degree of openness of an emerging market and the overall information environment, as reported by Bae, Bailey and Mao (2005). Bekaert, Harvey and Lumsdaine (2002) show a more direct relation between foreign inflows to the emerging markets and the decrease in the cost of capital after the liberalization. Furthermore, Huang and Shiu (2005) report that foreign institutions in Taiwan are regarded as more sophisticated than locals, better at forecasting firm performance, and active at monitoring management and demanding regulatory improvements.

Concerning other aspects, the evidence has been mixed. The hypothesis of excessive volatility upon the liberalization has been mostly unsupported by the data, as in Bekaert and Harvey (1997) and Kim and Singal (2000). The last study also offers evidence that the volatilities of inflation and exchange rate in emerging economies have dropped after the stock market liberalization. However, Dvorak (2001) shows the opposite: in the post-liberalization era, foreign trading can be related to increasing volatility on emerging markets. Moreover, Bae, Chan and $\mathrm{Ng}$ (2004) find that firms more open to foreign ownership are more volatile, while Domowitz and Coppejans (2000) report similar results for firms that cross-list. Concerning the role of foreign flows on Contagion, the evidence is also ambiguous: Kaminsky, Lyons and Schmukler (2004) find evidence consistent with foreign investors taking part in it, while Karolyi (2003) and Choe, Kho and Stultz (1999) fail to find such evidence. Besides, Kaminsky and Schmukler (2003) report evidence of emerging countries experiencing enlarged boom and bust cycles upon liberalization, but also argue that the liberalization should lead to increasing stability in the long term.

While the mentioned research mostly focused on the liberalization process, there have been very few studies concerning the effects of foreign flows on emerging markets after the liberalization ${ }^{4}$. In consequence, this paper

\footnotetext{
${ }^{3}$ In contrast, Edwards (1999) argues against capital controls in emerging countries for being costly and ineffective to avoid crises, and fostering corruption.

${ }^{4}$ Although the focus of those studies have been mainly to understand the characteristics and dynamics of institutional flows rather than their market wide effects, see for example, Froot, O'Connell and Seasholes (2001), Froot and Ramadorai(2001) and Richards(2005).
} 
aims to answer whether the foreign investors have an overall positive or negative effect in the liquidity of a set of emerging markets. Answering this question will add to our understanding of the role of foreign investors in emerging markets, and the associated benefits and costs. This research also intends to test in a wider sample of countries, the country-specific findings of Huang and Shui (2005) on foreign investors improving the information of the Taiwanese firms, and Choe, Kho and Stulz (2005) and Agudelo (2005) on foreign investors reducing liquidity on the firms and days where they trade the most, in Korea and Indonesia, respectively. This question also has a direct implication for the institutional investors that engage actively in herding as reported by Sias (2004) and Bowe and Domuta (2001), since decreasing liquidity in times of active foreign trading would make herding more costly.

To answer this question, first, we provide a case-study on the differential effects of foreign trading and foreign ownership on liquidity on a specific country, Indonesia. Next, we examine the market-wide effects of foreign trading and ownership for a group of seven emerging markets in a longer period of time. As a measure for liquidity, this paper uses the proportional quoted bid-ask spread.

The effects of foreign investors on the liquidity of emerging markets have been virtually unexplored, to our knowledge, by the extant literature, probably due to the difficulty of obtaining liquidity and foreign investor trading data. This paper overcomes this difficulty by using a detailed dataset on the Indonesia stock market that include foreign trading and ownership on a firm-day basis, as well as the Bloomberg database for daily data on bid-ask spreads and market-wide foreign activity for a group of emerging markets ${ }^{5}$. The most related papers to this research are Froot, O'Connell and Seasholes (2001) and Richards (2005) which find that foreign trading cause increased price pressure in emerging markets, but don't investigate the effects on liquidity. Besides, Choe, Kho and Stulz (2005) find that foreign investors have a larger price impact than locals on Korea, not driven by information but by investment style ${ }^{6}$.

This paper obtains two secondary results. First, we are able to explore the relationship between market liquidity and market return, volatility and turnover, providing an out-of-sample test of the findings of the systematic liquidity literature in US ( p.e. Chordia, Roll and Subrahmanyam 2001). Second, we are able to update the studies on the effects of foreign investors in emerging markets on prices ( p.e. Richards 2005) and volatility (p.e. Bekaert and Harvey 1997).

The remainder of this paper is organized as follows: Section 1 explains the hypothesis in the context of the empirical and theoretical literature, Section 2 presents the data, Section 3 explains the econometric model and discusses the results, and finally Section 4 provides the conclusion.

\footnotetext{
${ }^{5}$ The Indonesian database is used by Agudelo (2005) to measure the probability of informed trading by locals and foreigners. The Bloomberg databases of international bid-ask prices and foreign buys and sales has only begun to be used recently. For example, Lesmond (2005) uses it for his cross-sectional study of liquidity of emerging markets, Richards (2005) to study effects of foreign flows on returns and volatilities in six emerging markets, and Griffin, Nardari and Stulz (2005) to investigate the role of different type of investors in the relation between volume and return.

${ }^{6}$ In a related topic, Karolyi (2004) and Levine and Schmukler (2005) present evidence that the cross listing of stocks of emerging market firms as ADRs hurts the turnover of the home market. The second study provides evidence consistent with a story of diversion of trading from the home market to the US market upon the cross-listing.
} 


\section{Hypothesis}

We analyze the effects of foreign flows and foreign ownership on the liquidity of a group of emerging markets both at firm and market-level. In principle, we do not expect that foreign investors be any different from locals. In an efficient and transparent market, where both groups have access to the same information and are equally likely to be informed, foreign investors should be indistinguishable from domestic investors. Even in that stylized case, we can expect a minor beneficial effect of foreign flows: the inventory model of Ho and Stoll (1981) indicates that higher trading volumes are associated with higher liquidity, by reducing the inventory cost of liquidity providers, which is supported, among others, by the empirical evidence of Stoll (2000) and Lesmond (2005). Yet, an increased share of the traded volume by foreign investors should not have a significant effect on the liquidity of emerging markets, either at firm or market level, once we control for the effects of volume.

On the other hand, there is mounting evidence that foreign investors are more likely to be informed than the average local ${ }^{7}$. In that respect, Grinblatt and Keloharju (2000) provide evidence for Finland, Seasholes (2004) and Huang and Shiu (2005) for Taiwan, and Agudelo (2005) for Indonesia. Consequently, the asymmetric information models of Kyle (1987), Glosten and Milgrom (1987) and Easley and O'Hara (1987) imply that foreign investor trading will reduce liquidity, since it increases the probability of informed trading. Alternatively, Bonser-Neal et al (2005) y Choe, Kho and Stulz (2005) present evidence that foreign investors in Indonesia and Korea, respectively, demand liquidity more aggressively than locals, which is a non-informational explanation for the potential negative effects. Thus, to the null hypothesis of no effect from foreign investor trading we oppose the following alternative hypotheses:

H1: Foreign investor trading has a negative effect on the liquidity of individual stocks. This will be measured on a panel data regression of a liquidity measure against measures for the intensity of foreign investor trading and suitable control variables. This hypothesis implies a positive coefficient of the intensity of foreign investor trade.

On the other hand, we are also interested in exploring the market-wide effects of foreign investors on liquidity. Foreign institutions are presumably better informed than locals in macro variables, as suggested by Seasholes (2004) in Taiwan, Chan and Hameed (2005) in a cross-country study, Agudelo (2005) in Indonesia, and anecdotal evidence from financial analysts in emerging markets. Given that, the overall level of asymmetric information of firms in a market should increase in those times when foreign investors trade more intensively in a given direction. Moreover, Bae, Bailey and Mao (2005) show a positive relationship between the US portfolio flows and the information environment in 25 emerging markets. All in all, one can expect that market-wide foreign trading

\footnotetext{
${ }^{7}$ This is not contradictory to locals still having most of the information in the market as posed by the Home bias literature and Brennan and Cao(1997) and Griffin, Nardari and Stulz(2004), especially for medium and small size stocks as shown in Agudelo(2005)
} 
should be positively associated with the market-wide liquidity ${ }^{8}$. Market-wide (systematic) liquidity has been a notion explored by Chordia, Roll and Subrahmanyam (2000) ${ }^{9}$, Hasbrouck and Seppi (2001), and Chordia, Sakar and Subrahmanyam (2003) in the US stock market. As an alternative explanation, foreign trading might affect market-wide liquidity not through changing market-wide asymmetric information, but by causing increased order imbalance. Thus, the second hypothesis is:

H2: Market-wide foreign investor trading has a negative effect on the market-wide liquidity. This will be measured with a VAR model on seven emerging markets that includes also market-wide return, volatility and turnover. This hypothesis implies that shocks in foreign investor trading Granger-causes positive shocks on the measures of market-wide liquidity: average proportional spread.

Finally, there are reasons to expect a positive relationship between foreign ownership and liquidity. As a short term effect, if foreign buying is considered as a positive signal in emerging markets (Huang and Shui 2005, Richards 2005) increasing foreign ownership might lure local uninformed investors and/or liquidity providers, improving the trading activity and liquidity, in the same way that positive returns do, as in Griffin, Nardari and Stulz (2006). On the other hand, as a long term effect, the results of Huang and Shiu (2005) in Taiwan suggests that both, at market and firm level, foreigner ownership is a signal of improved information transparency and improved monitoring and that increased monitoring by foreigners will limit insider trading. Additionally, Bae, Bailey and Mao (2005) report that the fraction of stock available to foreign investors is related to an improved information environment at market level, for 25 emerging markets. Therefore, given that increased foreign ownership is related to reduced information asymmetry at firm or country level, it will attract larger numbers of uninformed traders, with the subsequent improvement on liquidity.

On the other hand, if foreign investors are more likely to be informed than locals, as mentioned before, increasing foreign ownership should discourage uninformed investors, and be negatively related to liquidity. In that sense, the evidence shows that foreign investors in emerging markets are predominantly institutions, and it has been established that institutions are, overall, better informed than individuals ${ }^{10}$ Alternatively, if foreign ownership increases exposure of a firm to world-wide factors and its volatility, as suggested by the results of Bae, Chan and $\mathrm{Ng}$ (2004), this might have a harmful effect on liquidity, since volatility decreases liquidity in the model of Ho and Stoll (1981), and the empirical papers of Chordia, Sakar and Subhramanyam (20055) and Lesmond

\footnotetext{
${ }^{8}$ Sadka(2005) discusses that the market-wide level of asymmetric information is priced in the US and can explain the momentum and postearning drift anomalies

${ }^{9}$ Chordia, Roll and Subhramanyam (2000) fail to relate the commonality on liquidity to common asymmetric information, consistent with their notion that "...little covariation in liquidity would be induced by asymmetric information because few traders possess privileged information about broad market movements" (p. 5). While this assertion seems reasonable for the US it is not necessarily true for smaller and less diversified markets as the ones we study here, as shown by Chan and Hameed (2005)

${ }^{10}$ In Korea and Taiwan most foreign trading is done by institutions as reported by Griffin, Nardari and Stulz (2005) and Huang and Shiu (2005). Dennis and Weston (2001) provide evidence and cite references in support of the hypothesis that institutions have better information than individuals.
} 
(2005). Nonetheless, Breen, Hodrick and Korajczyk (2002) provide evidence of a cross-sectional positive relationship between institutional ownership and liquidity

For the third hypothesis, we assume that the beneficial effect of foreign ownership on liquidity dominates:

H3. Foreign ownership is positively related with liquidity, both at firm and market-wide level. This will be tested in a panel-data model at firm-day level in Indonesia, and in a daily VAR model for seven emerging countries. The hypothesis implies, on the one hand, a negative coefficient of foreign ownership in the firmlevel panel data regression of the liquidity measures, and on the other hand that shocks in foreign ownership Granger-cause negative shocks on the measures of market-wide liquidity.

\section{Data}

\section{A Firm level data from Indonesia}

The tests at firm-day level are conducted using the data from Jakarta Stock Exchange (henceforth JSE), the main exchange of Indonesia, for the period April 2004 to March 2006. JSE is one ideal venue to study the effects of foreign investors on liquidity. Firstly, the JSE is a quite transparent market. At any given time, the investors can know not only the best bid and ask quotes and respective depths, but also the following five quotes and depths on both sides of the limit order book, in screens provided by different data vendors. Changes to the limit order book are updated in real time. After each transaction, agents in the market can observe not only the price and size of the transaction, but also the brokerage firm and the type, whether local of foreigner, of either party. This way, the market participants can tell if foreign or local investors are actively trading any given stock, and if they are net buying or selling. Secondly, JSE keeps a daily record of the buying and selling by foreign investors on each individual stock. Further market description of the JSE can be found in Bonser-Neal et al (1999) and (2005), Dvorak (2005) and Agudelo (2007).

From the JSE we obtain three separate datasets for the period April 2004 to March 2006. The first dataset compiles the daily trading statistics for each individual stock in the regular board. It includes open, maximum, minimum and closing prices, closing bid and ask prices and their respective depths, number of transactions, volume and value traded. The second dataset consists of the daily volume of shares sold and the volume of shares bought per stock by foreign investors in all the four boards of the exchange. Finally, the last dataset records every day the number of shares owned by foreign investors in each stock, along with the maximum allowed share of ownership for foreigners. Although in the past foreign investors were banned from owning more than 50\% in some strategic industries, these limits have been lifted, and since 1999 foreigners can own up to $100 \%$ in all types of firms, except banks, where they can still own up to 99\%. Thus, we don't expect that foreign ownership limits constitute an important factor in our analysis. 
After merging the three datasets, we eliminate those records pertaining to warrants and rights, ending with 359 stocks. Furthermore, we eliminate firm-days without valid quotes and stock months with less than 6 trading days in the month, ending with 88,512 stock-days. The summary statistics for the data are presented in Table I, for the size deciles and for the total sample. Most of the trading value and transactions take place in the top two size deciles, and foreigners actively trade in those, whereas they don't trade much on average in medium and small firms. Table I also shows that the ownership of foreign investors tends to be quite uniform across the size deciles, at an average of $16 \%$, but, at the same time, there is considerable variation across firms within the same size decile.

\section{B. Daily market wide data for seven Emerging markets}

The tests at daily market level are conducted on the seven emerging stock exchanges for which daily market data on foreign activity is available: India (Mumbai), Indonesia (Jakarta Stock Exchange), Korea (Korean Stock Exchange), Philippines (Philippines Stock Exchange), South Africa (Johannesburg Stock Exchange), Taiwan (Taiwan Stock Exchange) and Thailand (Stock Exchange of Thailand). The span of time available for each country is indicated in Table II. The Total daily values bought and sold by the foreign investors at market level were obtained from Bloomberg for India, Indonesia, Philippines, Taiwan and Thailand, and directly from the KSE for Korea. This data has already been used by Richards (2005), analyzing the effects of foreign flows in prices and returns for the period 1999-2001, and by Griffin, Nardari and Stulz (2006), studying the relation between turnover and return. For South Africa, Bloomberg provides the daily net value bought by foreign investors. To our knowledge, excepting KOSDAQ in Korea, the daily foreign investor variables are not available for any other exchange, limiting extending the analysis to other emerging markets ${ }^{12}$.

The market wide liquidity is estimated as the value weighted average of the proportional bid-ask spreads calculated from daily-stock quotes as in Chordia , Sakar and Subrahmanyam ( 2005 ). The quotes are obtained from Bloomberg, for India, Taiwan, Thailand and Korea, and from Datastream, for Indonesia and South Africa. In order to reduce the estimation error on this variable we take five steps: First, we drop invalid quotes, namely stock-days with missing bid or ask, or ask price equal or less than the bid. Second, we fill up missing quotes with the quotes from the former date if available. Third, in each market, we drop dates with less than 30 trading stocks. Fourth, after the three previous steps, we discard stocks with missing quotes on any of the trading days of a given year. And fifth, we drop the top $1 \%$ proportional spreads in the distribution of spreads of a given country in a given day. The weights used in the average come from the market capitalization firm data from Datastream ${ }^{13}$. The time series plots of the Value Weighted proportional spreads are presented in Figure 1.

\footnotetext{
${ }^{12}$ KOSDAQ, the second largest market from Korea, is not included in this analysis for the reduced participation of foreign investors. They traded only 1.1\% during 1999-2001 (Richards, 2005, p.5), and reached only $4.6 \%$ in average in 2004.

${ }^{13}$ Estimated as the number of outstanding shares (NOSH) multiplied by the adjusted price. Since NOSH data from Bloomberg is incomplete and unreliable, we use the Datastream NOSH. This requires that, for some countries, we merge the two databases using the SEDOL numbers, and manually complement this using the ticker and name of the stock. The percentage of matching firms by country was from 54\% for India, 99\% for Korea, 97\% for the Philippines, $97 \%$ for Taiwan and $83 \%$ for
} 
Other market wide variables are calculated as usual in the literature: returns as the change on the log of the main index in local currency units, volatility as the absolute value of the return, and turnover as the total trading value divided by the total market capitalization. This data was obtained from Bloomberg and complemented or corrected with Datastream as required ${ }^{14}$.

\section{Results}

\section{A. Firm level models in JSE}

We start by analyzing the effect of foreign trading at firm level in Indonesia. As mentioned above, from JSE we obtain daily buys and sells of foreign investors at firm level, for the period April 2004- March 2006. To estimate the effects of foreign trading on the stock liquidity we set up the following panel data model, similar to the one in Grullon, Kanatas and Weston (2004):

$$
\text { Liquidity }_{\mathrm{at}}=\mathrm{f}\left(\text { return }_{\mathrm{at}}, \text { volat }_{\mathrm{at}}, \text { turnover }_{\mathrm{at}}\right)[1]
$$

Where "a" stands for the firm, and " $\mathrm{t}$ " for the trading day. We use the log of proportional bid-ask spread as the liquidity measure. The model includes firm-fixed effects to filter out any firm specific effect and focus on the time-series effects as well as day-of-the-week dummies to filter any weekly seasonality. We control for the usual determinants of liquidity, namely the stock return, volatility, and volume . Column A of Table III presents the results of the basic time series model [1]. The firm specific variables turn out with the predicted sign: positive for volatility and negative for return, and volume, the first two being highly significant.

Next, we test Hypothesis 1, which asserts a negative relationship between foreign trading and the individual stock liquidity. For that, we include two measures of the intensity of foreign trading on a particular stock-day. The first is FITRADE, defined as the proportion of trade by foreigners in a given stock-day, and calculated as.

FITRADE $_{\mathrm{at}}=\left[\right.$ Foreigners sales $_{\mathrm{at}}$ (shares) + Foreign buys $_{\mathrm{at}}$ (shares) $] / 2 /$ Trading volume $_{\mathrm{at}}$ ( shares) ${ }^{16}$

Assuming that foreign investors are more likely to be informed than locals, we should expect a positive effect of FITRADE on the spreads. However, high FITRADE doesn't necessary indicate high informed trading. Agudelo

Thailand. Both databases have quotes for more than five years for all the seven emerging markets except India, and tend to agree quite well. Datastream quotes were preferred for the cases of Indonesia and South Africa for larger span and coverage. ${ }^{14}$ Having two or more alternative sources for each market variable allows us to check for entering data mistakes and to fill up missing values.

${ }^{16}$ Since JSE provides the total buying and selling by foreigners in the four boards (Regular, Negotiated, Crossing and Cash), for consistency, we use the total volume of the four boards, per stock and day, in the definitions of FITRADE and FIPRESSURE. 
(2005) shows in an extension to the PIN model of Easley, Kiefer and O'Hara (1997) that high trading volume days by foreigners can be explained by large uninformed or informed foreign trading or both. On the contrary, in the family of PIN models, high directional volume is identified with informed trading. Thus, we use FIPRESSURE, a proxy of the information content of foreign $\operatorname{trades}^{17}$, defined as follows:

FIPRESSURE $_{\mathrm{at}}=\operatorname{abs}\left[\right.$ Foreigners sale $_{\mathrm{at}}$ (shares) + Foreign buys $_{\mathrm{at}}($ shares $\left.)\right] / /$ Trading volume $_{\mathrm{at}}\left(\right.$ shares$_{\mathrm{at}}$

In days when foreign informed traders have good information in a given stock, they will tend to actively buy the stock, and conversely, bad information will result in a strong tendency to sell. Thus, FIPRESSURE approximates the probability of informed trading by foreigners in a given day. In consequence, and following Agudelo (2005), we expect a positive effect of FIPRESSURE on the liquidity measures. Moreover, the results of Choe, Kho and Stulz (2005) in Korea, and Bonser-Neal et al (2005) in Indonesia suggest that foreigners are more aggressive liquidity demanders, without implying any information advantage. Although, the two effects overlap to some degree, we expect that FITRADE be more a measure of liquidity demand by foreigners per se, whereas FIPRESSURE be more a measure of informed trading.

Columns B and C of Table III present the results of model [1] including alternatively the two measures of foreign trading. Both the coefficients of FITRADE and FIPRESSURE turn out positive and significant at the 1\% level, and remain so when we include both variables in Column D. This means that on stock-days when foreign investors are either trading a lot or aggressively trading in one direction, the liquidity of the stock decreases on average, as measured by the bid-ask spread. Columns $\mathrm{E}-\mathrm{H}$ test the robustness of this finding, by constraining the model respectively to the first half of the sample, the second half, the smaller firms, and the larger firms. We observe that, overall, the effects of FIPRESSURE are very robust, and tend to be larger in the size deciles 1 to 5, while the effects of FITRADE are absent only for the smaller firms.

These results are supportive of Hypothesis 1: foreign trading activity per se has a harmful effect on the liquidity of individual firms, consistent with aggressive liquidity demand, as in Bonser-Neal et al. (2005). Moreover when foreign trading has a strong buying or selling trend it reduces further the liquidity, consistent with foreigners investors trading on information at firm-level as in Seasholes (2004), Huang and Shui (2005) and Agudelo (2007). Besides, the liquidity demanding effects tend to be larger in larger firms, while the information effects tend to be larger in smaller firms.

Next, we investigate whether foreign investor trading is related to market-wide effects on the liquidity of the JSE. For that, we propose two measures of market wide trading activity of foreign investors: MKT_FITRADE, and MKT_FIPRESSURE, analogous to the already defined measures of firm specific foreign trading activity, and defined as follows:

\footnotetext{
${ }^{17}$ A better proxy of the information content, namely the order imbalance by foreigners, would have required transaction data.
} 
MK_FITRADE $_{\mathrm{at}}=\left[\right.$ Market Foreign sales $_{\mathrm{t}}(\$)+$ Market Foreign buys $\left._{\mathrm{t}}(\$)\right] / 2 /$ Market_Trading volume $_{\mathrm{t}}(\$)$

MK_FIPRESSURE $_{a t}=\operatorname{abs}\left[\right.$ Market Foreign sales ${ }_{t}(\$)-$ Market Foreign buys $\left.{ }_{t}(\$)\right]$ /Market_Trading volume

As defined MK_FITRADE is simply the proportion of the total trading value of the market due to foreign investors. It measures how actively foreigners trade in the market irrespective of their net buying or selling. MK_FIPRESSURE, on the other hand, will be high whenever the foreign investors are actively net selling or net buying in the market, and low in days when foreign sales are roughly as high as foreign buys. Thus, analogous to FIPRESSURE, we consider that MKT_FIPRESSURE serves as a proxy for the overall level of information of foreigners in the market.

Additionally, we need to control for the factors known to affect the level of market-wide liquidity. The literature on systematic liquidity has reported commonality patterns among the liquidity of individual stocks in US, and has explained part of that commonality as caused by market specific variables ${ }^{18}$. Accordingly, we include the following variables identified by the literature: the daily return of the market index, (MK_RETURN), the volatility of the market return (MK_VOLAT), and the log of the turnover of the market (MK_TURNOVER). The resulting model is presented in column $\mathrm{B}$ of Table IV. The sign of the coefficients of the market control variables is found as given by the empirical literature on systematic liquidity: negative coefficients of MK_RETURN, MK_TURNOVER, and positive coefficients of MK_VOLAT, all of them significant at the $1 \%$ level.

Next we include alternatively and together the variables of interest, MK_FITRADE and MK_FIPRESSURE, as presented in columns $\mathrm{C}$ to $\mathrm{E}$ of Table IV. Both variables show up with a significant and positive coefficient. This suggests that increasing foreign trading activity on the market reduces to some extent the liquidity of the stocks in the market. Over and above that effect, there is an incremental reduction on liquidity if foreigners are net buyers or net sellers in the market. Since we build the market wide model over the firm specific variable, the market-wide effect of foreigners goes beyond the firm-specific effect previously reported. In unreported tests we found the MK_FITRADE effect is robust after running it separately in the first and second half of the sample, and in the lower and upper halves by size decile. The MK_FIPRESSURE effects are significant only in the first half of the sample and for the larger firms. The economic effects are also important: an increase of one standard deviation in MK_FITRADE or MK_FIPRESSURE is related to an average rise of 5\% and 1\%, respectively, on the proportional spread.

Overall, the results support Hypothesis 2, in the sense that foreign trading is related with negative market wide effects on the liquidity of an emerging market such as Indonesia. Although causality from foreign trade to liquidity

\footnotetext{
${ }^{18}$ See for example, Chordia, Roll and Subrahmanyam (2000), Chordia, Sakar and Subrahmanyam(2003) and Fujimoto (2004)
} 
can't be inferred from those results, it's hard to think of any alternative explanation ${ }^{19}$. Anyway, causality will be tested later in a more adequate econometric model.

Columns $\mathrm{E}$ and $\mathrm{G}$ of Table IV incorporate alternatively two measures of market-wide liquidity in the empirical model: MK_EW_SPREAD, the equally weighted average of the proportional spreads across the stocks in the market, and MK_VW_SPREAD, the value weighted average of the proportional spreads. Clearly, the value weighted measure subsumes most of the effects of the market-wide variables, including the market foreign trading variables, while leaving unaffected the coefficients of the firm-specific variables ${ }^{20}$. Thus, we can argue that the market-wide effect of the foreign investors on liquidity is incorporated on the systematic liquidity of the market as measured by a Value Weighted average of proportional spreads. In the next subsection, we will study the relation between market foreign activity and market-wide liquidity in the context of a VAR model, for Indonesia and six other emerging markets.

Finally, we investigate the relation between foreign ownership and liquidity. Table $\mathrm{V}$ presents the results of a cross sectional regression of the liquidity on firm characteristics, based on Stoll (2000) and Lesmond (2005):

$$
\text { Liquidity }_{\mathrm{a} \mathrm{m}}=\mathrm{f}\left(\text { price }_{\mathrm{a} \mathrm{m}}, \text { Mkt_cap }_{\mathrm{a} \mathrm{m}}, \text { volume }_{\mathrm{a} \mathrm{m}}, \text { volat }_{\mathrm{a} \mathrm{m}}, \text { No_trades }_{\mathrm{a} \mathrm{m}}\right)
$$

Where 'a' stands for the firm and " $m$ " for the month. Liquidity a $m$ is the average proportional spread of the stock-month. The model includes month fixed effects, to control for any time dependentnt effects. The resulting coefficients are presented in the column A of Table $\mathrm{V}$. The $\mathrm{R}^{2}$ of the regression is quite high $(81 \%)$ and the coefficients of price, number of trades, and volatility appear significant and with the expected sign. On the contrary, volume and market capitalization turn out to be insignificant, probably because their effect is captured by number of trades and price.

When we include in the model the average proportion of foreign ownership, its coefficient in column B of Table $\mathrm{V}$ appears significant and negative. This result is robust to the inclusion of the average proportion of foreign trade, and to restrict the model to the first or second half of the period, and to the lower half or upper half of firms by size, as shown in columns 4 to 7 of Table V. The negative relation between foreign ownership and the proportional spread is also economically significant: A one standard deviation increase in the distribution of foreign ownership (18\%) is associated with a proportional reduction of $2.2 \%$ on the proportional spread.

Although these results are consistent with hypothesis 3, they are not enough to presume that foreign ownership improves the liquidity of the firms. The causality, if it exists at all, might run in the opposite direction: other things being equal, foreigners might well prefer liquid firms as suggested by Breen, Hodrick and Korajczyk (2002).

\footnotetext{
${ }^{19}$ For example, it is hard to think either that the causality runs from higher liquidity to higher foreign trade or of any omitted factor that might be causing the relation between liquidity and foreign trading.

${ }^{20}$ Again, this result is robust after running it separately in the first and second half of the sample, and in the lower and upper halves by size decile (not reported)
} 


\section{B. Market-wide models in seven emerging markets at daily frequency}

The results of the previous subsection for Indonesia suggest that foreign investor activity has negative effects on liquidity, not only at stock level but also at market level, as posed by Hypothesis 2. In this section, we further explore this question using a VAR specification for six emerging countries: India, Indonesia, Korea, the Philippines, Taiwan and Thailand. In some specifications a seventh market, SouthAfrica, will be included, for which only total daily net buys are available. VAR models have been used in the study of market-wide liquidity by Chordia, Sakar and Subrhamayan (2005) and Fujimoto (2004), and to study the interrelations of foreign flows with both cost of capital by Bekaert, Harvey and Lumsdaine (2002), and with returns by Richards (2005) and Griffin, Nardari and Stulz (2006).

We start with a base 4-VAR to model the dynamic behavior of four market-wide variables on a daily frequency: liquidity, measured as the log of the value-weighted average of the proportional bid ask spread, return as the change on the log of the main local country index, volatility as the absolute value of the return, and turnover as the total market traded value divided by the market capitalization. This set of variables has been used by Fujimoto (2004) in her monthly study of U.S liquidity. Chordia, Sakar and Subrhamayan (2005) use a similar set of variables in their daily VAR models of bond and stock market liquidity, but instead of turnover, they include a measure of market wide order imbalance, which has been found to have negative effects on liquidity. Unfortunately, the unavailability of transaction data impedes us in incorporating the order imbalance in our VAR model. The importance of controlling for other market variables that potentially affect market-wide liquidity, can't be understated. Foreign flows are hardly an exogenous variable in this context. For example, there is evidence of foreign flows both chasing returns and generating price pressure on emerging markets (Richards (2005), Choe Kho and Stulz (1999, 2005) ).

Next we discuss the expected effects on liquidity of the other three market variables. From an empirical point of view, Fujimoto (2004) and Chordia, Sakar and Subrhamanyam (2005) provide strong evidence that in US negative (positive) market returns Granger cause decreases (increases) in systematic liquidity. This has been explained as follows; liquidity providers find it more difficult to keep a balanced inventory in falling markets than in rising ones (Chordia, Roll and Subrahmanyam 2001). Volatility is a factor that reduces the utility of risk averse liquidity providers, hence reducing liquidity, in the inventory models of both Grossman and Miller (1988) and Ho and Stoll(1981). In US, portfolio volatility has been found to be positively related to proportional spread by Huberman and Halka (2001), and positive shocks in the stock market volatility induce negative shocks in the systematic liquidity as reported by Chordia, Sarkar and Subrahmanyam (2005) and Fujimoto (2004). The increase of trading reduces the inventory cost in both the models of Ho and Stoll (1981) of Grossman and Miller (1988). In a VAR model Fujimoto (2004) found that a positive innovation to aggregate turnover impacted negatively on both the proportional spread and the price impact. However, Chordia, Roll and Subrahmanyam, (2002) argue and provide evidence that, beyond turnover, an increase in the absolute value of order imbalance hurts liquidity, since 
it increases the inventory risk for the liquidity provider, or might signal private information. Thus, to the extent that turnover is correlated with order imbalance, the positive effect of turnover on liquidity might be decreased or even distorted in a model where order imbalance is omitted.

Before running the VAR model, we adjust the market variables to account for deterministic trends both in the mean and the variance, in a similar fashion to Chordia, Sarkar and Subrahmanyam (2005). Namely, if $w$ is either the vector of liquidity, returns, volatilities or any foreign investor variable, for each country ' $c$ ' we obtain the vector of residuals " $u$ " after controlling for a matrix of adjustment variables $x$ ', in the following mean equation:

$$
w_{c}=x^{\prime} \beta_{c}+u_{c}
$$

The vector of residuals is then regressed in the following equation of the variance:

$$
\log \left(u_{c}^{2}\right)=x^{\prime} \gamma_{c}+v_{c}
$$

The resulting predicted values of variance $x^{\prime} \gamma_{c}$ are then used to standardize the residuals of the mean equation as follows:

$$
A d j_{-} w_{c}=a_{c}+b_{c}\left[\hat{u} / \exp \left(x^{\prime} \gamma_{c} / 2\right)\right]
$$

Where $a_{c}$ and $b_{c}$ are calculated so that the means and variances of the adjusted variables are the same as those of the unadjusted series.

Following Chordia, Sakar and Subrahmanyam (2005) the adjustment variables are chosen as follows:

1. A dummy variables for each of four days of the week, to filter out any predictable weekly patterns.

2. Two crisis dummies, one for the Asian crises ( 07/2/97 through 31/12/97), the other for the Russian crises (7/6/98 through 12/31/98).

3. Eleven dummy variables for the month of the year.

4. A dummy variable for holiday effects, this is equal to one for a day preceding or following a holiday, unless it is in a weekend.

5. Linear and quadratic trend terms.

6. Individual dummies for days with too little trading activity, or with an outlier in any variable as detected by visual inspection of the residuals ${ }^{21}$.

\footnotetext{
${ }^{21}$ Two dummy variables for India ( 07/23/02, and 07/30/03 through 09/30/02), Four for Indonesia (03/23/98, 05/20/98, 03/24/98, 22/05/98), one for Korea (03/31/97), two for Philippines ( 01/22/01, 11/6/00), four for SouthAfrica (11/24/97, 12/28/99, 10/28/97, $10 / 29 / 97)$, one for Taiwan (1/3/05 through $2 / 25 / 05)$ and one for Thailand (4/25/00)
} 
With respect to turnover, following Griffin, Nardari and Stulz (2006), we detrend it by first, taking the logarithm and then substracting its 100-day moving average, a method that has been originally proposed by Lo and Wang (2000).

Next, we run an Adjusted Dickey-Fuller test (ADF) to check for the stationarity of each adjusted variable, allowing for an intercept, starting from 10 lags and stopping when the coefficient of the last lag turns out to be significant, as suggested by Enders (1995). For every adjusted variable in each country we reject the null hypothesis of not having a unit root at the 5\% significance level, and confirm this result with a Philipp-Perron Test (PP).

Initially, we set up a 4-VAR model per country, with the adjusted liquidity, return, volatility and turnover variables, for two reasons: first, as an out-of-sample test of the implications of the theory and of the findings of the systematic liquidity literature in the US stock market. And second, since the results of these country specific VAR models will give us an idea of the heterogeneity of the interrelations between variables before we incorporate the foreign investor variables. The 4-VAR model we propose can be expressed as the following system of four equations.

$$
X_{t}=\sum_{j=1}^{K} A_{j} X_{t-j}+u_{t}
$$

Where $X_{t}$ is the vector of market variables: $\log$ of the value weighted spread, index return, index volatility and turnover, and $u_{t}$ is the vector of innovations. We chose $K$ based on the Schwarz information criterion (SIC). Out of the three most used criteria (the others being AIC and HQC) the SIC has been found to consistently approximate the true number of lags and render the most parsimonious specification (Lütkephol 2004). The lags found by this criterion are two for India, Indonesia, Korea, Taiwan and Thailand, whereas one for the Philippines and South Africa. We first investigate the cross-correlations of the innovations from each one of the four equations of the VAR system. Significant correlations between innovations of two market variables suggest that they are subject to common influences or as evidence of unidirectional or bidirectional immediate causality between the two (Lütkephol 2005).

Panel A of Table VI reports, for each country, the cross-correlations of the innovations of each four equations. Focusing on the liquidity measure, we find the expected negative correlation with the innovations of the returns significant for the seven countries, and the positive relation with innovations of volatility, significant for five. These two empirical regularities have been reported for the US markets by Chordia, Roll and Subrahmanyam (2001). The expected negative relationship with innovations in turnover is only significant in two countries, whereas it is significantly positive in other two $^{22}$. Other than that, the seven countries present a significantly

\footnotetext{
${ }^{22}$ This ambiguous result might be explained by the fact that we are not controlling for order imbalance, which should have a negative effect to spreads, and might have a confounding effect on the turnover variable.
} 
positive correlation between innovations of volatility and innovations of turnover that has been well established in the literature.

Panel B of Table VI, in turn, presents the results of pairwise Granger causality tests between the variables of the country specific 4 -VAR models. The intersection of the row "i”" and column " $\mathrm{j}$ " reports the Chi-square value for the Wald test of the null hypothesis that the coefficients of the K lags of the variable "i" are jointly zero in the equation of variable " $\mathrm{j}$ ". Focusing on the first column we find that, overall, there is strong causality from returns, volatility and turnover on liquidity. As usual in the VAR methodology, we obtain the impulse response functions (IRFs) to estimate the size and sign of the causation ${ }^{23}$. The IRFs of the orthogonal innovations of the market variables on the liquidity measure are presented in Figure 2. For all the cases where a market variable Granger causes the liquidity measure, the impulse response function indicates a significant response and it is robust to the reordering of the variables (not reported). Taken together, the Granger causality results and the IRFs in the seven countries reinforce the findings of the cross-correlation of innovations. First, innovations on returns Granger cause opposite sign shocks in liquidity in four countries. Second, innovations on volatility Granger cause shocks of the same sign in spreads in four countries. And third, innovations on turnover Granger cause shocks of the opposite sign in spreads, also in four countries. Similar results in VAR models have been reported for US markets by the systematic liquidity literature, for example Chordia, Sakar and Subrahmanyam (2005) and Fujimoto (2004). We also found evidence of four well known empirical regularities: negative returns cause positive volatility shocks (four countries), positive spreads cause volatility increases (five countries), positive returns cause positive turnover shocks (six countries), and finally, positive volatilities cause increasing turnover (four countries). Finally, we note the heterogeneity in the results across countries: while there are three countries, India, Indonesia and Korea, where the four effects are robust, in Philippines and South Africa only one of the four effects shows up, and in Taiwan the only significant effect, returns on liquidity, appears with an unexpected sign.

Next, we include the foreign investor variable MK_FITRADE in the vector $X_{t}$ of market variables and run a 5VAR model for each country. We define this measure as in the former subsection, adjust it for deterministic trends as indicated before, and test its stationarity with the ADF and PP tests. As before, we select the number of lags by the SIC criteria, rendering two lags in every cases except for Korea and Taiwan, which require only one lag. Table VII presents the results of the 5-VAR model: Panel A the correlation matrix between the residuals of each equation and Panel B the results of the test for Granger causality.

We focus on the relation between MK_FITRADE and the liquidity variable. Table VII indicates a positive correlation between the residuals of the spreads and the residual of the foreign investor variable in India, Korea

\footnotetext{
${ }^{23}$ This requires that we first orthogonalize the innovations using the Cholesky decomposition, which in turn, requires posing an ordering of the variables. The IRFs are initially calculated with the following ordering: logVWspread, return, volatility and turnover, which conservatively understate the effects of the other variables on liquidity. However, for robustness, we also verify the IRFs obtained reversing this ordering and indicate in the text whenever the significance or direction of the IRFs qualitatively change with the ordering.
} 
and Taiwan, significant at the $5 \%$ level $^{24}$. This suggests that spreads tend to be high in days of strong foreign investor activity, as posed by Hypothesis 2. We examine two alternative explanations. First, this might be a spurious relationship, due to an omitted third market variable. To control for this, we run, for the three countries, a regression of the residual of the liquidity equation against the other residuals which confirms the significant positively effect (not reported). Second, the causality might run in the opposite direction: higher spreads might induce higher foreign trading, but this seems less realistic an explanation.

On the other hand, Panel B shows that we fail to find any Granger causality from MK_FITRADE to the spreads. Taken together, the evidence of Table VII is partially supportive of Hypothesis 2. Similar results are obtained if we use MK_FIPRESSURE instead (unreported). Restricting the models to the period after January 2000, to avoid the Asian and Russian crises, renders qualitatively the same results (unreported). Summarizing, there is some evidence of market wide effects from foreign trading in three countries, consistent with immediate causality but not with Granger causality.

As a collateral result, Panel A shows a negative relationship between returns and MK_FITRADE for five countries, whereas Panel B and the corresponding impulse response functions (omitted) show that higher returns Granger cause lower trading by foreigners. This basically replicates the results of Griffin, Nardari and Stulz (2006) in the sense that locals more than foreigners drive the positive return-turnover relation. The authors comment that "Under the assumption that foreign investors are more sophisticated than domestic investors, this evidence could also be consistent with the view that the (return-turnover) relation is stronger among unsophisticated investors" ( p. 24)

Next, we explore Hypothesis 3 with a different 5-VAR daily model. Whereas in the last part we measured the effect due to increasing foreign trading, here we are interested on the effects of an increasing ownership by foreigners. Accordingly, we define the variable MK_FINETBUY as a measure of the daily increase in the Market Foreign ownership, as follows:

MK_FINETBUY ${ }_{\mathrm{at}}=\left[\right.$ Market Foreign buys $_{\mathrm{t}}(\$)-$ Market Foreign sales $\left._{\mathrm{t}}(\$)\right] /$ Market_capitalization $\mathrm{t}(\$)$

Note that this variable can be estimated for South Africa, unlike MK_FITRADE, which makes a total of seven emerging markets. We adjust this variable for deterministic trends and seasonality in the mean and variance as described above, and test it with the ADF and PP tests of stationarity. We add this variable to the vector $X_{\mathrm{t}}$, to obtain a 5-VAR system which is, again, estimated country by country. As before, the lags of the VARs are obtained by the SIC criteria, two lags for all the countries, except Taiwan which requires three.

\footnotetext{
${ }^{24}$ Having three significant correlations out of six is highly significant: the probability of having three or more significant correlations out of six by chance is $0.2 \%$, assuming independentnce and having a $5 \%$ individual significance.
} 
The results of the 5-VAR model with MK_FINETBUY are presented in the Table VIII. We focus on the relations with the foreign investor variable. Starting on Panel B we note that an increasing ownership in emerging markets Granger causes the spreads in India and Korea at the 5\% level ${ }^{25}$. The impulse response functions, in Figure 3 , show that for those two countries the effects are unambiguously negative, and significantly lasting about one to two weeks. Moreover, reversing the order of the variables for the Cholesky decomposition confirms that the negative effect is robust. In addition, the IRFs for South Africa and Thailand also show a negative effect from MK_FINETBUY to the spreads, significant at the $10 \%$ level, when the foreign variable precedes the spreads in the Cholesky decomposition, but not when the order of variables is reversed ${ }^{26}$. Panel A reports a negative and significant relationship between the residuals of the liquidity and the foreign investor equations. However, this correlation is of very small magnitude and disappears once we control for the other residuals (unreported). The overall result is robust and even improved when we examine the results of a unreported 2-VAR model with only the spreads and the foreign net buy variable. Overall, the results of Table VIII support Hypothesis 3, in the sense that an increasing foreign ownership benefits liquidity, even in the short term. As indicated in Section 2 this could be explained by foreign buying being regarded as a positive signal in the emerging markets attracting uninformed traders and liquidity providers, and improving the market wide liquidity, similarly to positive returns.

Table VIII also shows a strong bidirectional relation between foreign net buy and returns: Panel A shows a significant positive correlation between the two for all the countries except South Africa. Furthermore, Panel B shows bidirectional Granger causality for India, Taiwan and Thailand, while the causality runs only from the returns to the foreign investor trade for Indonesia, Korea and Philippines. Figure 4 presents the impulse response functions of returns to orthogonal innovations of the foreign variable, and viceversa. For the cases where Granger causality appears, the direction of the responses is always positive and robust to the reordering of the variables (not reported). This is strong evidence of two effects that have been already reported in the literature: on the one hand, positive returns causing positive foreign net buys are evidence of trend following and/or positive feedback trading by foreign investors as reported by Froot, O'Connell and Seasholes(2001), Bekaert, Harvey and Lumsdaine (2002) and Richards (2005); on the other hand, positive foreign net buys causing positive returns is evidence of price pressure as reported by Richards (2005), Choe Kho and Stulz (1999, 2005) or information content as in Froot and Ramadorai (2001). However, if information were the cause of this return increase, the classical market microstructure models would imply a contemporaneous or lagged positive relation between the foreign investor variable and the spreads, which is not observed for any of the seven countries ${ }^{27}$. On the contrary, using transaction data from Korea, Choe, Kho and Stulz(1995) provide evidence consistent with foreigner trading

\footnotetext{
${ }^{25}$ Having two significant relations out of seven is significant at the customary level: the probability of having two significant correlations out of six by chance is $4.4 \%$, assuming independentnce and having a $5 \%$ individual significance.

${ }^{26}$ The negative effects on the spreads appear for all the countries, and Granger causality is significantly obtained at the $5 \%$ level for India, Korea and South Africa, and marginally at the $10 \%$ level for Taiwan.

${ }^{27}$ No significant lagged or contemporaneous effect on spreads is observed either, using, as the foreign variable, the absolute value of market foreign net buys.
} 
causing price pressure, but not evidence of superior information. All in all, the evidence suggests that price pressure is a better explanation of this relation between foreign net buys and returns.

Finally, we examine one last issue the effects of foreign investors on volatility. Neither Panel B of VII, nor Panel B of Table VIII show foreign investor activity Granger causing volatility at market level. The only exception is Taiwan in Table VIII, but the causality is of the unexpected sign: increasing foreign ownership Granger causes reduced volatility. Contemporaneous correlations between the residuals of the foreign variables and volatility are inexistent in Table VIII and ambiguous in Table VII. ${ }^{28}$. This result supports the findings of Bekaert and Harvey (1997) and Kim and Singal (2000) of no significant effects on volatility from foreign investors.

\section{Conclusion}

Lately the international finance literature has advanced in its understanding of the role of foreign investors in emerging markets. More is known about the effects of foreigners on information, price formation, volatility and returns in those markets. We contribute to that literature by estimating the effects of foreign trading and foreign ownership on liquidity.

Overall, we have found that foreign trading has a harmful, although short lived, effect on liquidity, at firm level as well as at market level. We explored two possible explanations for this effect. While, this could be explained in terms of foreign investors being, in average, better informed than locals, the evidence presented here tilts to a rather mechanic reason: foreigners seem to be per se more aggressive liquidity demanders than locals.

On the other hand, we have found some evidence that firm ownership has beneficial effects on the liquidity of emerging markets, not only in a cross-sectional regression for individual stock in Indonesia, but also at market level in India and Korea, among three other exchanges. At firm level, the finding that foreign ownership is related to increased liquidity seems consistent with foreigners either preferring more liquid or transparent firms, or causing firms to become more informationaly efficient. On the other hand, at market level, increasing foreign ownership in India and Korea appears to be causing an important and permanent improvement in liquidity in a horizon of about two weeks. Although the classical market microstructure models might suggest as an explanation that foreigners improve the information environment, we don't find this compelling at such a short horizon. Instead, we offer as an alternative explanation that foreign buying (selling) attracts noise traders and liquidity providers to the market, very much in the same sense that positive returns seem to do.

\footnotetext{
${ }^{28}$ Panel A of Table VIII shows two countries with positive correlation between foreign activity and volatility, India and Korea, and one with negative correlation, Indonesia. While one might think that this effect is stronger in times of financial crises, note that for all the countries, except India and Philippines, the sample include the Russian crises, and that for Indonesia, Korea, South Africa and Taiwan, the sample include the Asian crisis.
} 
The results of this paper also provide an out-of-sample test of the empirical findings reported by the systematic liquidity literature in the US. We find strong effects from returns and volatility on the market wide liquidity in seven emerging markets. 


\section{References}

Agudelo, D. 2005. "Home advantage or Big fish? Do Local or Foreigner traders know more about the Indonesian Market?. Working paper, Indiana University

Amihud, Y., 2002. Illiquidity and Stock Returns: Cross Section and Time-Series Effects, Journal of Financial Markets, 5, 31-56.

Bae, K., Chan, K., Ng, A., 2004. Investibility and return volatility. Journal of Financial Economics 71, $239-263$.

Bae, K-H. Bailey W. and Mao C.X. 2005, Stock Market Liberalization and the Information Environment. Working paper, Korea University, Cornell University and Temple University.

Bekaert, G and Harvey, C., 2003. Emerging markets Finance. Journal of Empirical Finance 10, 3-57

Bekaert, G. and Harvey, C.R., 1995. Time-varying world market integration. Journal of Finance 50, $403-444$.

Bekaert, G. and Harvey, C.R., 1997. Emerging equity market volatility. Journal of Financial Economics 43, $29-78$.

Bekaert, G. and Harvey, C.R., 2000. Foreign speculators and emerging equity markets. Journal of Finance 55, 565614.

Bekaert, G., Harvey, C.R. and Lumsdaine, R.L. 2002. The dynamics of emerging market equity flows. Journal of International Money and Finance, 21 295-350.

Bekaert, G., Harvey, C.R. and Lundblad, C., 2005. Liquidity and expected returns: lessons from emerging markets. Working paper, Duke University, Durham, NC.

Bekaert, G., Harvey, C.R., 1997. Emerging equity market volatility. Journal of Financial Economics 43, $29-78$.

Bonser-Neal, C., Jones, S. L., Linnan, D, and Neal, R. 2005. Liquidity, Price Impact and Foreign Trading: Does Identity Matter?. Indiana University. Working Paper

Bortolotti, B., de Jong, F., Nicodano, G., Schindele, I. (2004). Privatization and Stock Market Liquidity. Working Paper University of Turín.

Bowe, M. and Domuta, D. 2001, "Foreign investor behavior and the Asian financial crisis". Journal of International Financial Markets, Institutions and Money 11, 395-422.

Breen, W., Hodrick, L. S., Korajczyk R. A., 2002, Predicting equity liquidity, Management Science, 48, 470-483.

Brennan, M., H. Cao, 1997, International portfolio investment flows, Journal of Finance, 52, 1851-1880.

Chan, K., and A. Hameed, 2005, Stock price synchronicity and analyst coverage in emerging markets, Journal of Financial Economics, forthcoming

Choe H., Kho, B-C, and Stulz, R. 2005."Do domestic investors have an edge? The trading experience of foreign investors in Korea," Review of Financial Studies, 2005, v18 3.795-829.

Choe, H., Kho, B-C, and Stulz R., 1999, Do foreign investors destabilize stock markets? The Korean experience in 1997, Journal of Financial Economics 54, 227-264.

Chordia, T., Roll, R. and Subrahmanyam A. 2001. Market Liquidity and Trading Activity. The Journal of Finance., 56 501-530.

Chordia, T., Roll, R. and Subrahmanyam A., 2000. Commonality in Liquidity, Journal of Financial Economics, 56 328.

Chordia, T., Roll, R. and Subrahmanyam A. 2002. Order Imbalance, Liquidity and Market Returns. Journal of Financial Economics, 65, 111-130

Dennis, P.J. and Weston, J.P. Who's Informed?. 2001. An analysis of Stock Ownership and Foreign Trading. Working Paper, University of Virginia and Rice University.

Domowitz, Glen and Madhavan (2001). Liquidity, Volatility and Equity Trading Costs Across Countries and Over Time, International Finance 4:2, 221-255.

Domowitz, I. and Coppejans, M. (2000) "The Impact of Foreign Equity Ownership on Emerging Market Share Price Volatility," International Finance 3, 95-122.

Easley, D. and O’Hara, M., 1987, Price, Trade Size, and Information in Securities Markets, Journal of Financial Economics 19, 69-90

Easley, D., Kiefer, N., and O'Hara, M. 1997, One Day in the Life of a Very Common Stock, Review of Financial Studies, 10, 805835.

Edwards, S. 1999 "International Capital Flows and the Emerging Markets: Amending the Rules of the Game?" Federal Reserve Bank of Boston Conference Series 43, June 1999, pp. 137-57.

Eichengreen, B. 1999. Toward a New International Financial Architecture. Institute of International Economics, Washington, DC.

Ellul, A. and Pagano, M. 2005. IPO Underpricing and After-Market Liquidity, forthcoming Review of Financial Studies. 
Errunza, V.R., Miller, D.P., 2000. Market segmentation and the cost of capital in international equity markets. Journal of Financial and Quantitative Analysis 35, 577-600.

Enders, W. (1995). Applied Econometric Time series. John Wiley \& Sons.

Ffrench-Davis, R. and Griffith-Jones S. 2002. Capital Flows to Developing Countries

since the Asian Crises: How to Manage their Volatility. Working paper UNU/WIDER Research Project.

Freeman, N.J. and Bartels, F. L. 2000. Portfolio Investment in Southeast Asia's Stock Markets: A survey of investor perceptions, The Asia Pacific Journal of Economic and Business, 4, 28-58

Froot, K., and Ramadorai, T., 2002. The information content of international portfolio flows. Forthcoming Review of Financial Studies.

Froot, K.A., O'Connell, P.G. and Seasholes, M. S. 2001., The portfolio flows of international investors, Journal of Financial Economics, 59, 151-193.

Fujimoto, A., 2004. Macroeconomic Sources of Systematic Liquidity. Working Paper, Alberta University.

Ghysels and Cherkaoui, 2003. Emerging markets and trading costs: lessons from Casablanca. Journal of Empirical

Finance 10, 171-200.

Glosten, L. R. and Milgrom, P. R., 1985, Bid, Ask, and Transaction Prices in a Specialist Market With

Heterogeneously Informed Traders, Journal of Financial Economics 14, 71-100.

Griffin, J. M., Nardari, F., and Stulz, R. 2004, Daily cross-border flows: pushed or pulled?, The Review of Economics and Statistics 86, 641-657.

Griffin, J. M., Nardari, F., and Stulz, R. 2006 Do investors trade more when stocks have performed well? Evidence from 46 countries, Forthcoming Review of Financial Studies.

Grinblatt, M., M. Keloharju, 2000, The investment behavior and performance of various investor-types: A study of Finland's unique data set, Journal of Financial Economics 55, 43-67.

Grullon, G., Kanatas, G., and Weston, J.P., 2004, “Advertising, Breadth of Ownership, and Liquidity,” Review of Financial Studies 17, 439-461.

Hasbrouk, J. and Seppi, D.J., 2001, .Common factors in prices, order flows, and liquidity. Journal of Financial Economics 59, 383-411.

Henry, P.B., 2000. Stock market liberalization, economic reform, and emerging market equity prices. Journal of Finance 55, 529- 564.

Ho, T. and Stoll, H.R. 1981. Optimal Dealer Pricing under Transactions and Return Uncertainty. Journal of Financial Economics 9, 47-73.

Hölmstrom, B. and Tirole, J. 1993. Market Liquidity and Performance Monitoring, Journal of Political Economy, 101, 678-709.

Huang, R.D and Shiu C-Y. 2005. Overseas Monitors in Emerging Financial Markets: Evidence from Foreign Ownership in Taiwan. University of Notre Dame.

Huberman, G. and Halka D. 2001. Systematic Liquidity. The Journal of Financial Research 24, 161-178.

Ito, T. and Portes, R.1998. "Dealing with the Asian Financial Crises." European Economic Perspectives, CERP.

Kaminsky, G. and Schmukler, S., 2003. "Short-Run Pain, Long-Run Gain: The Effects of Financial Liberalization," IMF Working Papers 03/34, International Monetary Fund

Kaminsky, G., Lyons R.K., and Schmukler, S., 2004, Managers, investors, and crises: Mutual fund strategies in emerging markets, Journal of International Economics 64, 113-134.

Karolyi, A. 2004. The Role of ADRs in the Development of Emerging Equity Markets. Review of Economics and Statistics 86, 670-690.

Kim, E.H., and Singal, V., 2000. Stock market openings: Experience of emerging economies. Journal of Business 73 , 25-66.

Krugman, Paul. 1998. "What Happened to Asia?" Unpublished paper. MIT

Kyle, A.S., 1985, Continuous Auctions and Insider Trading, Econometrica 53, 1315-1335.

Lesmond, D.A., 2005. Liquidity of Emerging Markets. Journal of Financial Economics. 77, 411-452.

Levine, R. and Schmukler, S. 2005. Internationalization and Stock Market Liquidity. Working Paper 9614. NBER

Levine, R.2003 Stock Market Liquidity and Economic Growth: Theory and Evidence" in Finance, Research, and

Education, and Growth eds. Luigi Paganetto and Edmund S. Phelps, New York: Palgrave MacMillan, 1-24

Lo, A. W., and J., Wang, 2000, Trading Volume: Definitions, Data Analysis, and Implications of Portfolio Theory,

Review of Financial Studies, 13, 257-300

Lütkephol, H. 2004. Vector autoregressive and Vector Correction Model. Chapter 3. in Applied Time Series

Econometrics, Edited by H. Lütkephol, and M. Krätzig. Cambridge University Press. Cambridge, U.K.

Lütkephol, H. 2005. New Introduction to Multiple Time Series Analysis. Springer-Verlag, Berlin. pp. 764,

Miller, D. P., 1999. The impact of international market segmentation on securities prices: evidence from Depositary

Receipts. Journal of Financial Economics 51, 103- 123.

Richards, A., 2005. Big fish in small ponds: The trading behavior of foreign investors in Asian emerging equity 
markets. Journal of Financial and Quantitative Analysis 40, 1-27.

Rubin, Robert and Jacob Weisberg (2003). In an Uncertain World: Tough Choices from Wall Street to Washington. New York: Random House.

Sadka, R., 2005, Liquidity Risk, and Asset Pricing, forthcoming Journal of Financial Economics.

Seasholes, M.S., 2004, Re-examining information asymmetries in emerging stock markets, working paper, U. C. Berkeley. 33

Sias, R.2004. "Institutional Herding.” Review of Financial Studies, 17 165-206.

Standard and Poors 2004. Global Stock Markets Factbook. New York: Mac-Graw Hill.

Stiglitz, J.E., 2000. Capital market liberalization, economic growth and instability. World Development 25, 1075 1086.

Stoll H.R. 2000. Friction. The Journal of Finance, 55 1479-1514. 

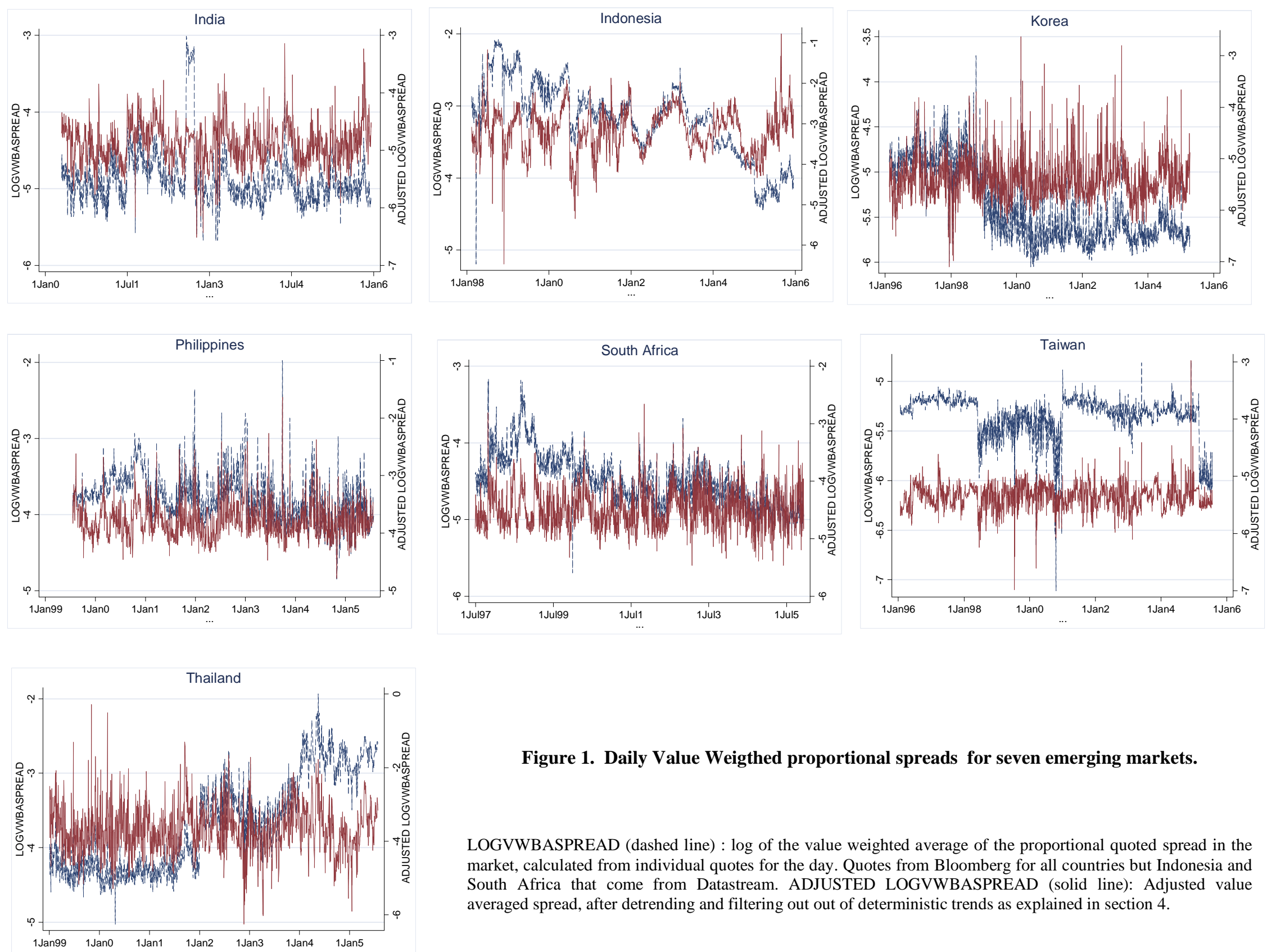

Figure 1. Daily Value Weigthed proportional spreads for seven emerging markets.

LOGVWBASPREAD (dashed line) : log of the value weighted average of the proportional quoted spread in the market, calculated from individual quotes for the day. Quotes from Bloomberg for all countries but Indonesia and South Africa that come from Datastream. ADJUSTED LOGVWBASPREAD (solid line): Adjusted value averaged spread, after detrending and filtering out out of deterministic trends as explained in section 4 
India IRF: RETURN -> VWBASPREAD

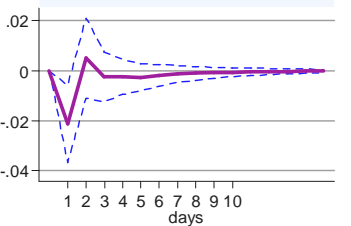

IRF: VOLAT -> VWBASPREAD

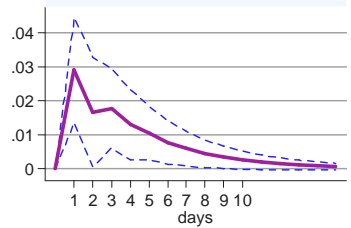

IRF: TURNOVER $>$ VWBASPREAD

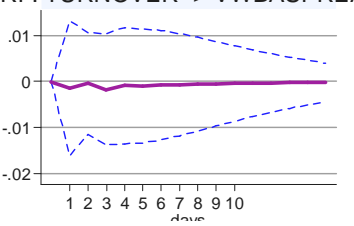

South Africa

IRF: RETURN -> VWBASPREAD

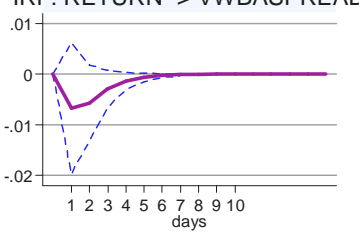

IRF: VOLAT -> VWBASPREAD

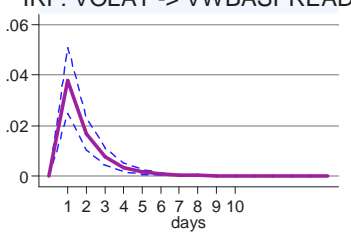

IRF: TURNOVER -> VWBASPREAD

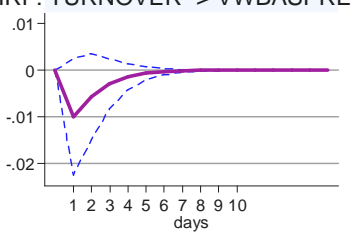

Indonesia

IRF: RETURN -> VWBASPREAD

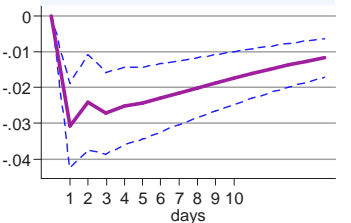

days

IRF: VOLAT -> VWBASPREAD

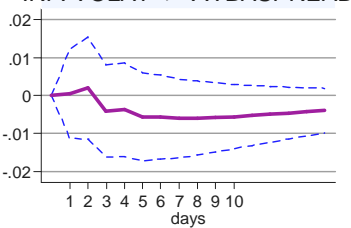

IRF: TURNOVER -> VWBASPREAD

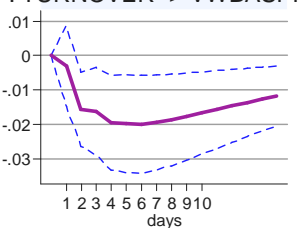

Korea

IRF: RETURN -> VWBASPREAD

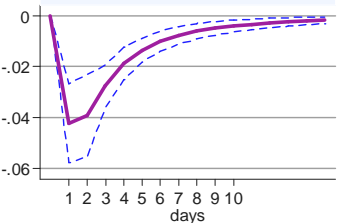

IRF: VOLAT -> VWBASPREAD

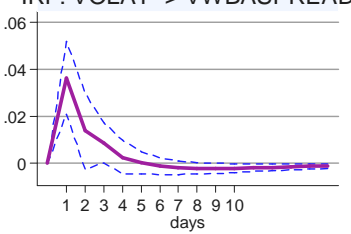

Philippines

IRF: RETURN -> VWBASPREAD

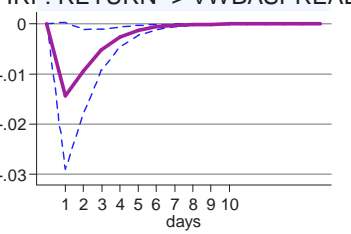

IRF: VOLAT -> VWBASPREAD

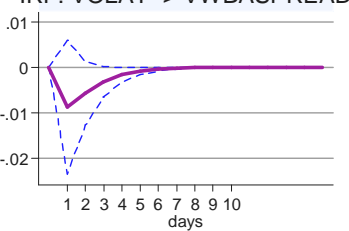

IRF: TURNOVER -> VWBASPREAD IRF: TURNOVER -> VWBASPREAD

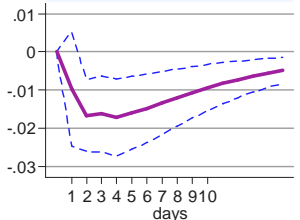

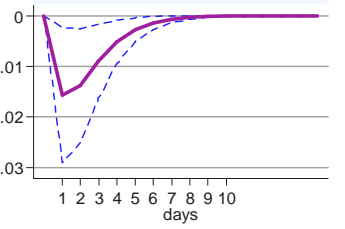

Taiwan

IRF: RETURN -> VWBASPREAD

.03-

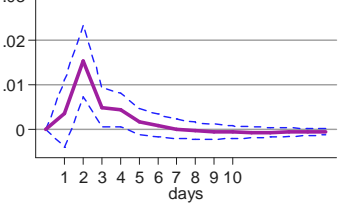

IRF: VOLAT -> VWBASPREAD

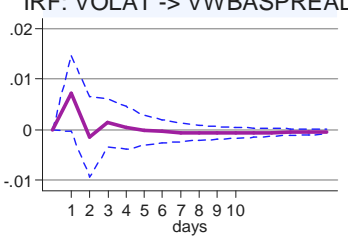

IRF: TURNOVER -> VWBASPREAD

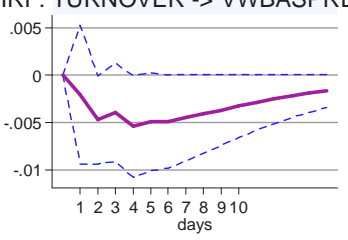

Thailand

IRF: RETURN -> VWBASPREAD

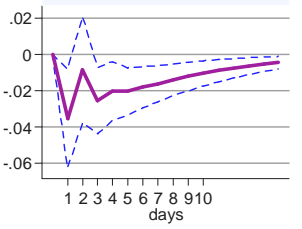

IRF: VOLAT -> VWBASPREAD

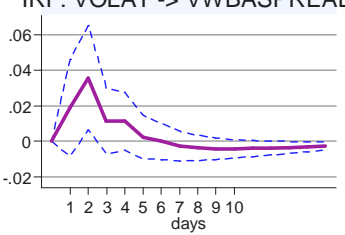

IRF: TURNOVER -> VWBASPREAD

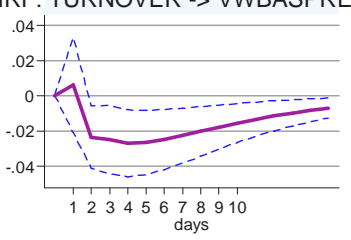

Fig 2 Impulse response functions of orthogonalized innovations from market variables on liquidity for seven emerging markets

The IRFs are calculated from the results of a 4-VAR model with daily endogenous variables VWBASPREAD, RETURN, VOLAT and TURNOVER. The 4-VAR is estimated with a constant, and 2 lags for all cases, except Philippines and South Africa with only one lag. The Impulse response functions are obtained after a Cholesky decomposition, assuming an ordering VWBASPREAD, RETURN, VOLAT and TURNOVER. VWBASPREAD: log of the value weighted average of the proportional quoted spread in the market, calculated from individual quotes for the day. Quotes from Bloomberg for all countries but Indonesia and South Africa that come from Datastream. Value weights from individual market capitalization from Datastream. Remaining market variables come mostly from Bloomberg, and complemented with Datastream as needed: RETURN: change on the log of the main market index. VOLAT: Absolute value of RETURN. TURNOVER, log of the market turnover estimated as Total trading value/ Total market capitalization. The variables were detrended and filtered out of deterministic trends as explained in section 4 . Confidence intervals of $95 \%$ in dashed lines. 
India

IRF1: FINETBUY -> VWBASPREAD

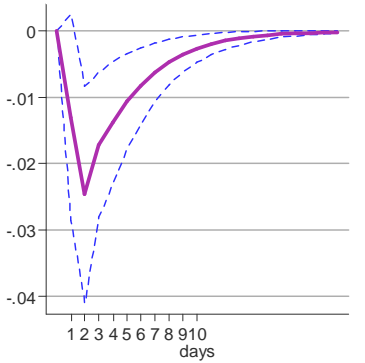

IRF2: FINETBUY -> VWBASPREAD

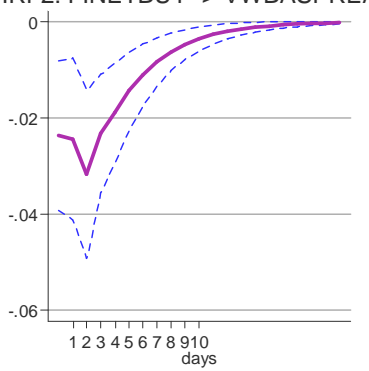

Indonesia

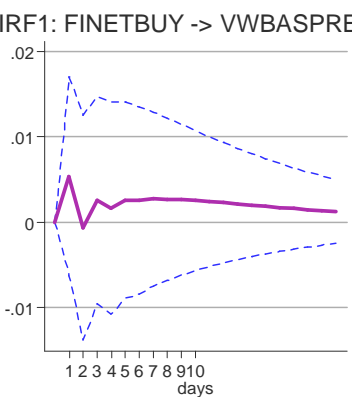

IRF2: FINETBUY -> VWBASPREAD

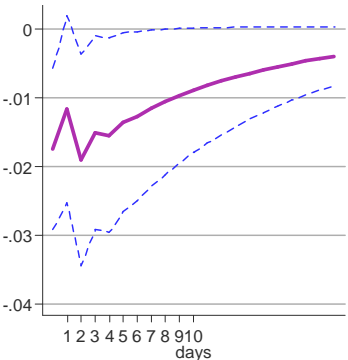

Korea

IRF1: FINETBUY -> VWBASPREAD

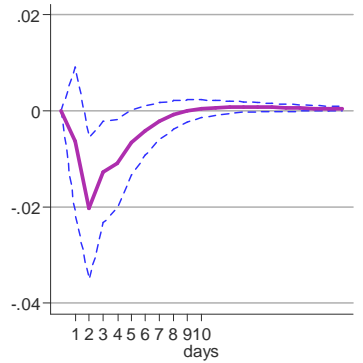

IRF2: FINETBUY -> VWBASPREAD

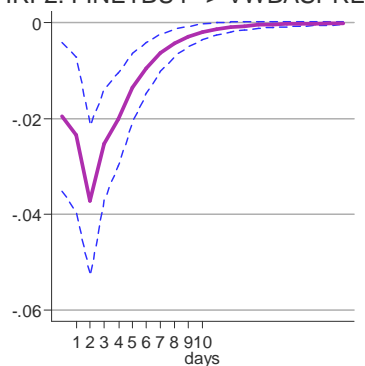

Philippines

IRF1: FINETBUY -> VWBASPREAD

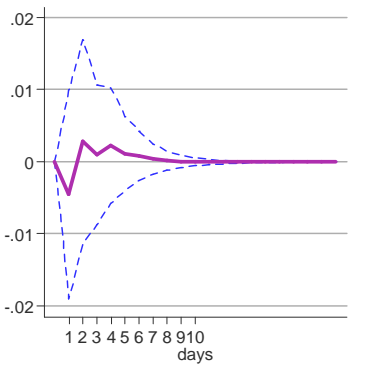

IRF2: FINETBUY -> VWBASPREAD

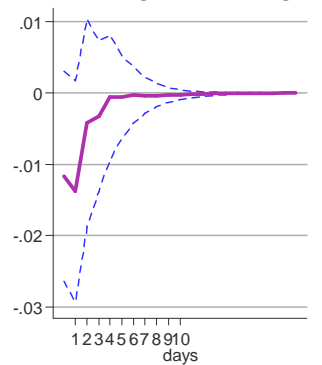

South Africa

IRF1: FINETBUY -> VWBASPREAD

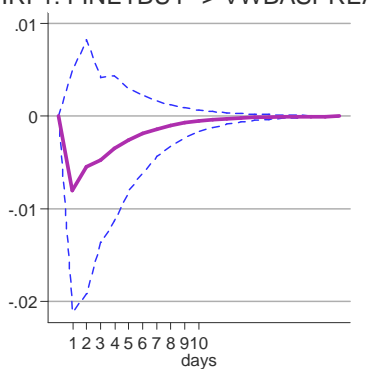

IRF2: FINETBUY -> VWBASPREAD

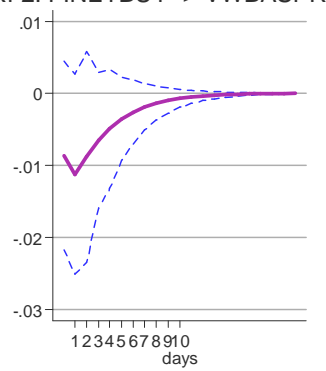

Thailand

IRF1: FINETBUY -> VWBASPREAD

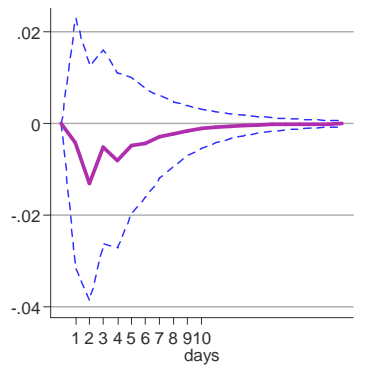

IRF2: FINETBUY -> VWBASPREAD

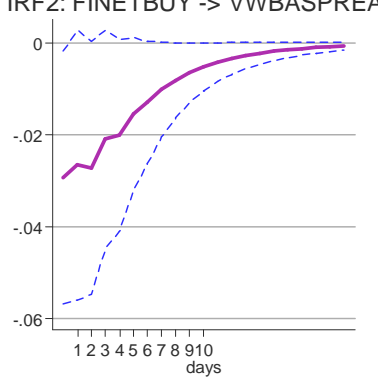

Taiwan

IRF1: FINETBUY -> VWBASPREAD

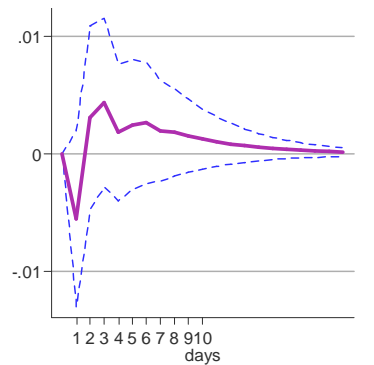

IRF2: FINETBUY -> VWBASPREAD

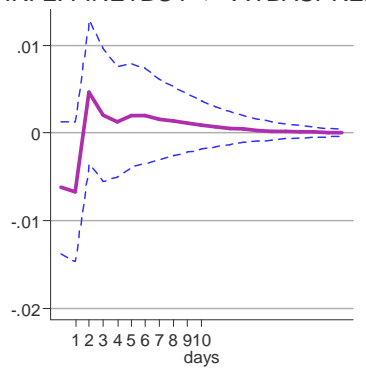

Fig 3 Impulse response functions of orthogonalized innovations from Foreign net buy on liquidity for seven emerging markets

The IRFs are calculated from the results of a 5-VAR model with daily endogenous variables VWBASPREAD, RETURN, VOLAT, TURNOVER and FINETBUY. The 5-VAR is estimated with a constant, and 2 lags for all cases, except Korea and Taiwan with three lags. The Impulse response functions IRF1 are obtained after a Cholesky decomposition, assuming an ordering VWBASPREAD, RETURN, VOLAT, TURNOVER and FINETBUY, whereas The impulse response functions IRF2 assume the reverse ordering. VWBASPREAD: log of the value weighted average of the proportional quoted spread in the market, calculated from individual quotes for the day. Quotes from Bloomberg for all countries but Indonesia and South Africa that come from Datastream. Value weights from individual market capitalization from Datastream. Remaining market variables come mostly from Bloomberg, and complemented with Datastream as needed: RETURN: change on the log of the main market index. VOLAT: Absolute value of RETURN. TURNOVER, log of the market turnover estimated as Total trading value/ Total market capitalization. FINETBUY: Total Net buys by foreigners in the market, calculated as: [Foreigners buys (LCU) - Foreign sales $(\mathrm{LCU})$ ] / Market capitalization (LCU) The variables were detrended and filtered out of deterministic trends as explained in section 4. Confidence intervals of $95 \%$ in dashed lines. 
India

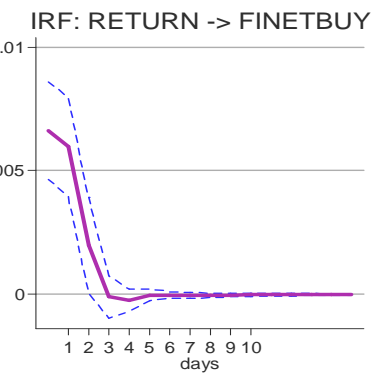

IRF: FINETBUY -> RETURN

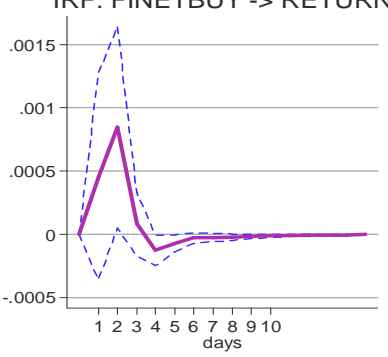

Indonesia

IRF: RETURN -> FINETBUY

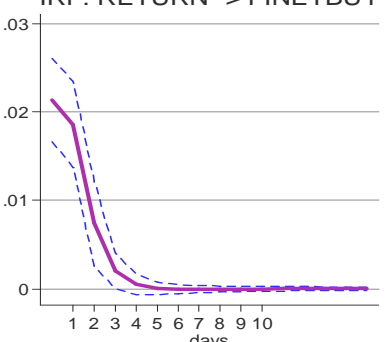

IRF: FINETBUY -> RETURN

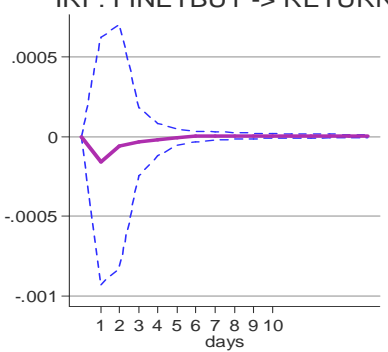

Korea

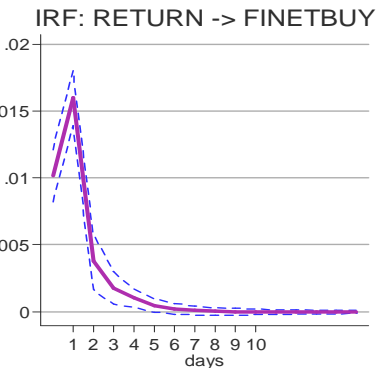

IRF: FINETBUY -> RETURN

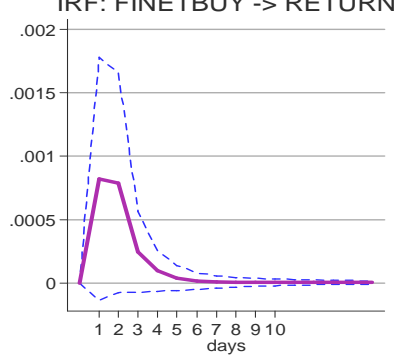

Philippines

IRF: RETURN -> FINETBUY

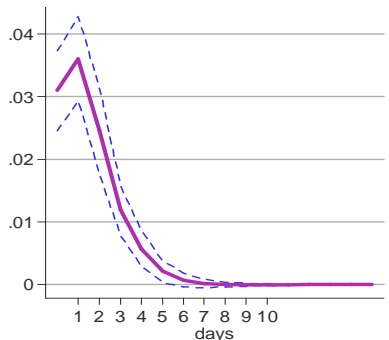

IRF: FINETBUY -> RETURN

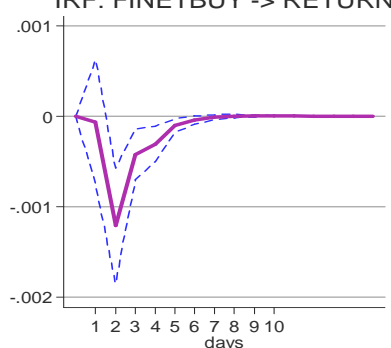

\section{South Africa}

IRF: RETURN -> FINETBUY

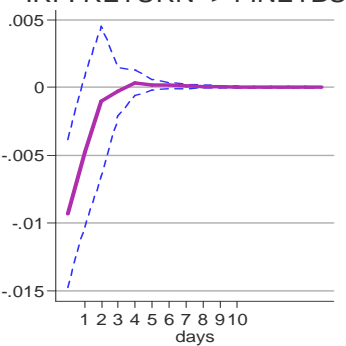

IRF: FINETBUY -> RETURN

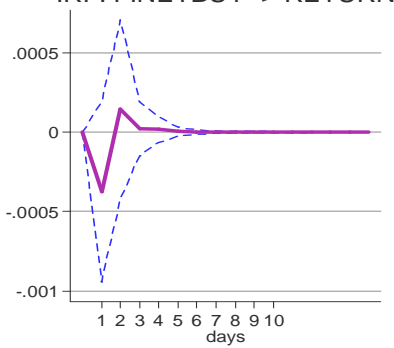

Taiwan
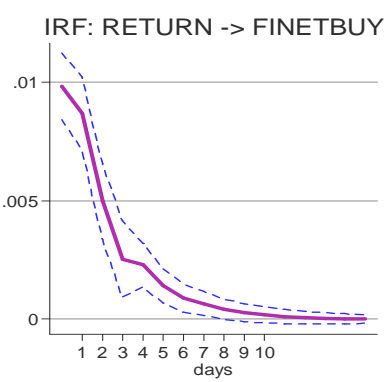

IRF: FINETBUY -> RETURN

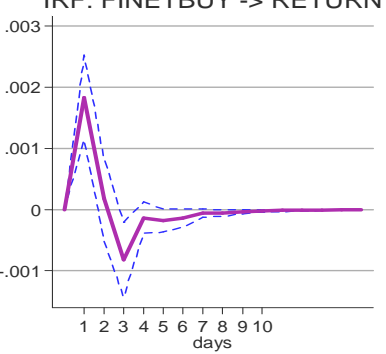

Thailand

IRF: RETURN -> FINETBUY
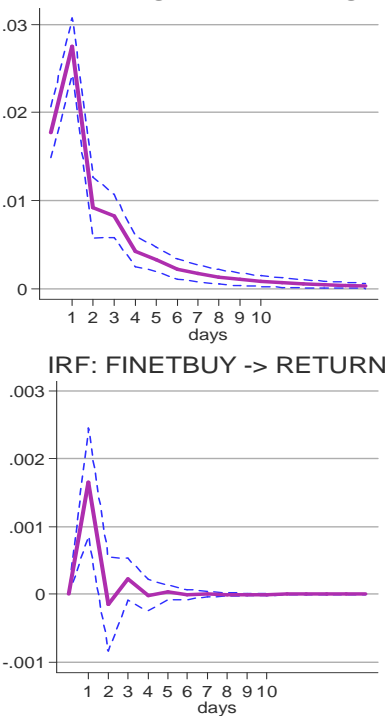

Fig 4 Impulse response functions of orthogonalized innovations from Return on Foreign net buy and viceversa for seven emerging markets

The IRFs are calculated from the results of a 5-VAR model with daily endogenous variables VWBASPREAD, RETURN, VOLAT, TURNOVER and FINETBUY. The 5-VAR is estimated with a constant, and 2 lags for all cases, except Korea and Taiwan with three lags. The Impulse response functions are obtained after a Cholesky decomposition, assuming an ordering VWBASPREAD, RETURN, VOLAT, TURNOVER and FINETBUY. VWBASPREAD: log of the value weighted average of the proportional quoted spread in the market, calculated from individual quotes for the day. Quotes from Bloomberg for all countries but Indonesia and South Africa that come from Datastream. Value weights from individual market capitalization from Datastream. Remaining market variables come mostly from Bloomberg, and complemented with Datastream as needed: RETURN: change on the log of the main market index. VOLAT: Absolute value of RETURN. TURNOVER, log of the market turnover estimated as Total trading value/ Total market capitalization. FINETBUY: Total Net buys by foreigners in the market, calculated as: [Foreigners buys (LCU) - Foreign sales (LCU)] / Market capitalization (LCU) The variables were detrended and filtered out of deterministic trends as explained in section 4 . Confidence intervals of $95 \%$ in dashed lines. 


\section{Table I. Summary statistics of Jakarta Stock Exchange}

\begin{tabular}{|c|c|c|c|c|c|c|c|c|c|c|c|}
\hline \multirow[t]{2}{*}{$\begin{array}{l}\text { Size } \\
\text { Decile }\end{array}$} & \multirow[t]{2}{*}{$\begin{array}{l}\text { Trade } \\
\text { value } \\
\text { (billion } \\
\text { rupiah) }\end{array}$} & \multirow[t]{2}{*}{$\begin{array}{l}\text { Number of } \\
\text { Trades }\end{array}$} & & \multirow{2}{*}{$\begin{array}{l}\text { Foreign } \\
\text { pressure } \\
\text { mean }\end{array}$} & \multirow{2}{*}{$\begin{array}{l}\text { turnover } \\
\text { mean }\end{array}$} & \multirow[t]{2}{*}{$\begin{array}{l}\text { Proportional } \\
\text { quoted spread }\end{array}$} & \multirow{2}{*}{$\begin{array}{l}\text { Mkt. } \\
\text { capitalization } \\
\text { mean }\end{array}$} & \multicolumn{3}{|c|}{$\begin{array}{l}\text { \% Foreign investor } \\
\text { ownership }\end{array}$} \\
\hline & & & mean & p 95 & & & & & mean & p5 & p95 \\
\hline 1 & 90 & 23.0 & $1.9 \%$ & $10.4 \%$ & $0.010 \%$ & $0.332 \%$ & $12.1 \%$ & 14,913 & $17.6 \%$ & $0.1 \%$ & $50.6 \%$ \\
\hline 2 & 115 & 22.2 & $1.4 \%$ & $7.4 \%$ & $0.007 \%$ & $0.269 \%$ & $9.9 \%$ & 29,394 & $10.4 \%$ & $0.0 \%$ & $48.6 \%$ \\
\hline 3 & 65 & 14.3 & $2.8 \%$ & $20.0 \%$ & $0.007 \%$ & $0.093 \%$ & $9.3 \%$ & 60,977 & $16.5 \%$ & $0.4 \%$ & $55.9 \%$ \\
\hline 4 & 162 & 21.3 & $3.4 \%$ & $30.2 \%$ & $0.004 \%$ & $0.129 \%$ & $8.3 \%$ & 117,493 & $13.5 \%$ & $0.0 \%$ & $42.1 \%$ \\
\hline 5 & 248 & 25.7 & $5.8 \%$ & $50.0 \%$ & $0.006 \%$ & $0.148 \%$ & $5.1 \%$ & 151,112 & $15.3 \%$ & $0.0 \%$ & $38.8 \%$ \\
\hline 6 & 574 & 42.2 & $3.8 \%$ & $30.3 \%$ & $0.010 \%$ & $0.190 \%$ & $5.2 \%$ & 290,692 & $21.2 \%$ & $0.7 \%$ & $63.0 \%$ \\
\hline 7 & 669 & 39.2 & $9.4 \%$ & $50.0 \%$ & $0.010 \%$ & $0.132 \%$ & $4.5 \%$ & 523,349 & $13.5 \%$ & $0.9 \%$ & $39.9 \%$ \\
\hline 8 & 1965 & 52.0 & $11.6 \%$ & $50.0 \%$ & $0.016 \%$ & $0.248 \%$ & $3.4 \%$ & $1,008,397$ & $16.4 \%$ & $0.3 \%$ & $46.1 \%$ \\
\hline 9 & 4752 & 102.0 & $15.5 \%$ & $55.2 \%$ & $0.019 \%$ & $0.217 \%$ & $3.1 \%$ & 2,391,294 & $18.3 \%$ & $2.0 \%$ & $50.9 \%$ \\
\hline 10 & 23262 & 216.7 & $34.3 \%$ & $77.1 \%$ & $0.019 \%$ & $0.164 \%$ & $1.5 \%$ & $19,900,000$ & $20.3 \%$ & $1.6 \%$ & $57.3 \%$ \\
\hline otal & 4496 & 68.8 & $11.2 \%$ & $53.9 \%$ & $0.012 \%$ & $0.190 \%$ & $5.4 \%$ & $2,687,820$ & $16.3 \%$ & $0.0 \%$ & $50.9 \%$ \\
\hline
\end{tabular}

The deciles of market capitalization are given by the average market capitalization during 2005. Traded value and number of trades are averages of the daily values for the entire period, including non-trading days. \% Foreign investor trade is an average of the daily values of (Foreign sales + Foreign buys)/2/ volume. Fipressure is a magnitude of directional trade by foreign investors:abs (Foreign buys - Foreign sales )/2/ volume. Turnover is volume divided by market capitalization. Proportional bid-ask spread is the average of (ask-bid)/((ask+bid)/2) whenever quotes are available. Market capitalization and $\%$ of Foreign Investor ownership are averages for the first quarter of 2006. \% Foreign Investor Ownership is the proportion of listed shares owned by investors. Exclude stock-months with less than 5 trading days. Total sample: 359 firms. Period: April 2004 to March 2006. Source: Jakarta Stock Exchange. 
Table II. Summary statistics of daily market data for seven emerging markets

\begin{tabular}{|c|c|c|c|c|c|c|c|c|c|c|c|c|}
\hline \multirow[t]{2}{*}{ Country } & \multicolumn{2}{|c|}{ Period } & \multirow[t]{2}{*}{$\begin{array}{l}\text { Number of } \\
\text { trading days }\end{array}$} & \multirow{2}{*}{$\begin{array}{l}\text { Turnover } \\
\text { mean }\end{array}$} & \multirow{2}{*}{$\begin{array}{l}\text { Foreign } \\
\text { mean }\end{array}$} & \multirow{2}{*}{$\begin{array}{l}\text { Investor } \\
\min \end{array}$} & \multirow{2}{*}{$\begin{array}{l}\text { Trade } \\
\max \end{array}$} & \multirow{2}{*}{$\begin{array}{l}\text { Foreign } \\
\text { pressure } \\
\text { mean }\end{array}$} & \multicolumn{3}{|c|}{ VWbaspread } & \multirow[t]{2}{*}{$\begin{array}{l}\text { Source for } \\
\text { quotes }\end{array}$} \\
\hline & Start & End & & & & & & & mean & $\min$ & $\max$ & \\
\hline India & $4 / 18 / 00$ & $12 / 15 / 05$ & 1417 & $0.761 \%$ & $7.0 \%$ & $0.2 \%$ & $33.4 \%$ & $0.016 \%$ & $0.8 \%$ & $0.3 \%$ & $4.9 \%$ & Bloomberg \\
\hline Indonesia & 2/11/98 & $12 / 15 / 05$ & 1914 & $0.155 \%$ & $29.3 \%$ & $0.0 \%$ & $67.6 \%$ & $0.013 \%$ & $4.7 \%$ & $0.6 \%$ & $12.5 \%$ & Datastream \\
\hline Korea & $2 / 16 / 96$ & $4 / 12 / 05$ & 2244 & $0.824 \%$ & $11.2 \%$ & $1.0 \%$ & $45.2 \%$ & $0.032 \%$ & $0.5 \%$ & $0.2 \%$ & $2.4 \%$ & Bloomberg \\
\hline Philippines & $7 / 20 / 99$ & $7 / 26 / 05$ & 1490 & $0.067 \%$ & $48.9 \%$ & $2.0 \%$ & $77.8 \%$ & $0.008 \%$ & $2.4 \%$ & $0.8 \%$ & $13.9 \%$ & Bloomberg \\
\hline South Africa & $6 / 27 / 97$ & $12 / 9 / 05$ & 2115 & $0.158 \%$ & & . & & $0.014 \%$ & $1.2 \%$ & $0.3 \%$ & $4.2 \%$ & Datastream \\
\hline Taiwan & $1 / 23 / 96$ & $7 / 26 / 05$ & 2329 & $0.918 \%$ & $7.0 \%$ & $0.3 \%$ & $36.2 \%$ & $0.021 \%$ & $0.5 \%$ & $0.1 \%$ & $0.8 \%$ & Bloomberg \\
\hline Thailad & $1 / 4 / 99$ & $7 / 26 / 05$ & 1610 & $0.418 \%$ & $25.9 \%$ & $3.7 \%$ & $57.8 \%$ & $0.021 \%$ & $3.2 \%$ & $0.7 \%$ & $14.4 \%$ & Bloomberg \\
\hline
\end{tabular}

Summary statistics of daily market data for seven Emerging Markets. Number of trading days is the total number of days included in the sample, excluding days with less than 30 trading stocks and saturdays for Korea and Taiwan. Turnover estimated as Total trading value/ Total market capitalization. MK FITRADE: Proportion of the market total trading value by Foreigners, calculated as: [Market Foreign sales (\$) + Market Foreign buys (\$)] /2/ Market_Trading volume (\$). MK_FIPRESSURE: abs[Market Foreign sales t (\$) - Market Foreign buys t (\$)]]/ Total_Market_capitalization (\$) ). VWbaspread is the daily Value weighted proportional spread, calculated from daily quotes and using Datastream Market capitalization as weights. 
Table III. Effects of Foreign Trading on Liquidity at firm-day level

\begin{tabular}{|c|c|c|c|c|c|c|c|c|c|c|c|c|c|c|c|c|}
\hline & A & & B & & $\mathrm{C}$ & & $\mathrm{D}$ & & $\mathrm{E}$ & & $\mathrm{F}$ & & G & & $\mathrm{H}$ & \\
\hline RETURN & -0.163 & & -0.159 & & -0.159 & & -0.158 & & -0.233 & $* *$ & -0.044 & & -0.285 & $* *$ & 0.052 & \\
\hline VOLAT & 1.637 & $* *$ & 1.638 & $* *$ & 1.635 & $* *$ & 1.637 & $* *$ & 1.053 & $* *$ & 1.545 & $* *$ & 1.474 & $* *$ & 1.878 & $* *$ \\
\hline TURNOVER & -0.103 & $* *$ & -0.105 & $* *$ & -0.104 & $* *$ & -0.105 & $* *$ & -0.099 & $* *$ & -0.090 & $* *$ & -0.100 & $* *$ & -0.109 & $* *$ \\
\hline FIPRESSURE & & & & & 0.220 & $* *$ & 0.120 & $* *$ & 0.061 & $*$ & 0.099 & $* *$ & 0.326 & $* *$ & 0.114 & $* *$ \\
\hline $\begin{array}{l}\text { Size Deciles } \\
\text { Period }\end{array}$ & $\begin{array}{c}\text { All } \\
\text { Apr } 04-\text { Mar } \\
06\end{array}$ & & $\begin{array}{c}\text { All } \\
\text { Apr } 04 \text { - Mar } \\
06\end{array}$ & & $\begin{array}{c}\text { All } \\
\text { Apr } 04-\text { Mar } \\
06\end{array}$ & & $\begin{array}{c}\text { All } \\
\text { Apr } 04 \text { - Mar } \\
06\end{array}$ & & $\begin{array}{c}\text { All } \\
\text { Apr } 04-\text { Mar } \\
05\end{array}$ & & $\begin{array}{c}\text { All } \\
\text { Apr } 05-\text { Mar } \\
06\end{array}$ & & $\begin{array}{c}1-5 \\
\text { Apr } 04-\text { Mar } \\
06\end{array}$ & & $\begin{array}{c}6-10 \\
\text { Apr } 04-\text { Mar } \\
06\end{array}$ & \\
\hline $\mathrm{N}$ & 88512 & & 88512 & & 88512 & & 88512 & & 46304 & & 42208 & & 30195 & & 58317 & \\
\hline $\mathrm{R}^{2}$ & 0.708 & & 0.709 & & 0.709 & & 0.709 & & 0.738 & & 0.781 & & 0.606 & & 0.611 & \\
\hline
\end{tabular}

Regressand: Daily change on the log of the proportional bid-ask spread at daily level, for stocks from Jakarta Stock Exchange (JSE), Indonesia, from April 2004 to March 2005. Stock months with less than 6 trading days were eliminated. Includes omitted constant, firm-specific and day-of-the-week dummy variables. RETURN: change on the log of price of the stock, adjusted for splits. VOLAT: square residual of the return. TURNOVER: log of the trading value scaled down by the market capitalization. FITRADE: proportion of the trading volume due to foreigners, calculated as: [Foreigners sales (shares) +Foreign buys (shares)]/2/Trading volume (shares). FIPRESSURE: absolute value of net buys by foreigners, calculated as: abs[Foreigners sales +Foreign buys]/ Shares outstanding.

$*, * *$ : Robust standard errors significant at $5 \%$ and $1 \%$ level, respectively 
Table IV Effects of Market Foreign Trading on Liquidity at firm-day level

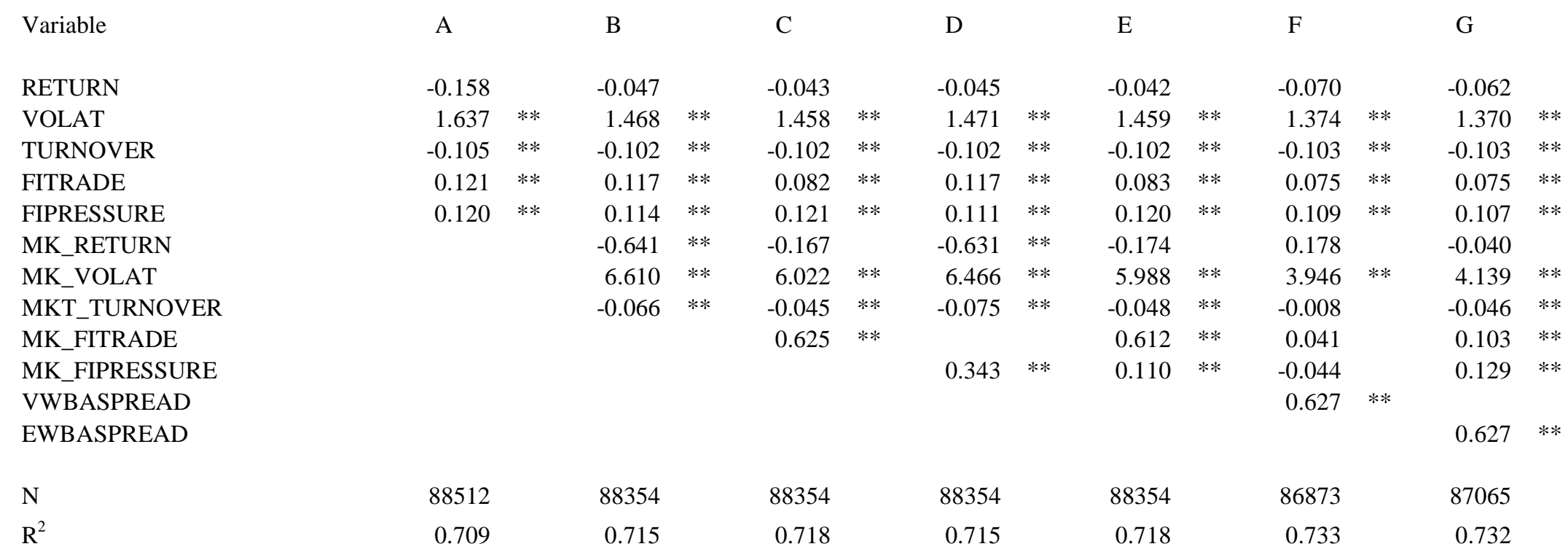

Regressand: Daily change on the log of the proportional bid-ask spread at daily level, for stocks from Jakarta Stock Exchange (JSE), Indonesia, from April 2004 to March 2005. Stock months with less than 6 trading days were eliminated. Includes omitted constant, firm-specific and day-of-the-week dummy variables. RETURN: change on the log of price of the stock, adjusted for splits. VOLAT: square residual of the return. TURNOVER: log of the trading value scaled down by the market capitalization. FITRADE: proportion of the trading volume due to foreigners, calculated as: [Foreigners sales (shares) +Foreign buys (shares)]/2/Trading volume (shares). FIPRESSURE: absolute value of net buys by foreigners, calculated as: abs[Foreigners sales +Foreign buys]/ Shares outstanding. Market level data taken from Bloomberg: MK_RETURN: change on the log of the JSE index. MK_VOLAT: Absolute value of MK_RETURN. MK_TURNOVER, log of the market turnover estimated as Total trading value in JSE/ Total market capitalization of JSE. MK_FITRADE: Proportion of the market total trading value by Foreigners, calculated as: [Market Foreign sales $t(\$)+$ Market Foreign buys $t(\$)$ ] $/ 2 /$ Market_Trading volume t (\$). MK_FIPRESSURE: abs[Market Foreign sales t (\$) - Market Foreign buys t (\$)]]/ Total_Market_capitalization t. MK_EW_SPREAD: log of the equally weighted average of the proportional spread in the market. MK_VW_SPREAD: log of the value weighted average of the proportional spread in the market, using market capitalization as weights.

$*, * *$ : Robust standard errors significant at $5 \%$ and $1 \%$ level, respectively 
Table V Effects of Foreign Ownership on Liquidity at stock-month level

\begin{tabular}{|c|c|c|c|c|c|c|c|c|c|c|c|c|c|}
\hline & A & & B & & $\mathrm{C}$ & & $\mathrm{D}$ & & $\mathrm{E}$ & & $\mathrm{F}$ & & G \\
\hline PRICE & -0.312 & $* *$ & -0.310 & $* *$ & -0.315 & $* *$ & -0.344 & $* *$ & -0.280 & $* *$ & -0.422 & $* *$ & -0.278 \\
\hline MARKET CAP & -0.009 & & -0.011 & & -0.019 & $*$ & -0.018 & & -0.021 & & 0.002 & & -0.005 \\
\hline VOLUME & 0.012 & & 0.014 & & 0.008 & & 0.050 & $* *$ & -0.022 & & -0.033 & & 0.028 \\
\hline VOLAT & 9.558 & $* *$ & 9.546 & $* *$ & 9.404 & $* *$ & 8.349 & $* *$ & 11.814 & $* *$ & 7.215 & $* *$ & 11.016 \\
\hline No_TRADES & -0.252 & $* *$ & -0.254 & $* *$ & -0.246 & $* *$ & -0.290 & $* *$ & -0.220 & $* *$ & -0.144 & $* *$ & -0.290 \\
\hline FI_OWNERSHIP & & & -0.113 & $* *$ & -0.125 & $* *$ & -0.149 & $*$ & -0.109 & $*$ & -0.119 & $*$ & -0.165 \\
\hline FITRADE & & & & & 0.230 & $* *$ & 0.128 & & 0.301 & $*$ & 0.331 & & 0.043 \\
\hline $\begin{array}{l}\text { Size Deciles } \\
\text { Period }\end{array}$ & $\begin{array}{c}\text { All } \\
\text { Apr } 04-\text { Mar } \\
06\end{array}$ & & $\begin{array}{c}\text { All } \\
\text { Apr } 04-\text { Mar } \\
06\end{array}$ & & $\begin{array}{c}\text { All } \\
\text { Apr } 04-\text { Mar } \\
06\end{array}$ & & $\begin{array}{c}\text { All } \\
\text { Apr } 04-\text { Mar } \\
05\end{array}$ & & $\begin{array}{c}\text { All } \\
\text { Apr } 05-\text { Mar } \\
06\end{array}$ & & $\begin{array}{c}1-5 \\
\text { Apr } 04-\text { Mar } \\
06\end{array}$ & & $\begin{array}{c}6-10 \\
\text { Apr } 04-\text { Mar } \\
06\end{array}$ \\
\hline $\mathrm{N}$ & 4483 & & 4483 & & 4483 & & 2360 & & 2123 & & 1538 & & 2945 \\
\hline $\mathrm{R}^{2}$ & 0.809 & & 0.810 & & 0.811 & & 0.791 & & 0.834 & & 0.731 & & 0.747 \\
\hline
\end{tabular}

Regressand: log of the average proportional bid-ask spread for each stock-month. Data from Jakarta Stock Exchange (JSE), Indonesia, from Apr-2004 to Mar 2006. Regressions include omitted constant, and month dummy variable.. PRICE : Log of the last closing price of the month. MARKET_CAP: Log of the average market capitalization in Rupiahs. VOLAT : average of the absolute value of the returns. VOLUME: log of the average trading value in Rupiahs. No_TRADES: Log of the average daily number of transactions. FI_OWNERSHIP: Average share of the firm owned by foreign investors. FITRADE: average proportion of the trading volume due to foreigners, calculated as: [Foreigners sales (shares) +Foreign buys (shares)] /2/ Trading volume (shares)

$*, * *$ : Robust standard errors significant at $5 \%$ and $1 \%$ level, respectively 
Table VI. Granger causality results for a 4 -VAR daily country model with liquidity

Panel A . Correlations between VAR innovations

\begin{tabular}{|c|c|c|c|c|c|}
\hline & & VWBASPREAD & RETURN & VOLAT & TURNOVER \\
\hline \multirow[t]{4}{*}{ India } & VWBASPREAD & 1.00 & & & \\
\hline & RETURN & -0.39 & 1.00 & & \\
\hline & VOLAT & 0.14 & -0.10 & 1.00 & \\
\hline & TURNOVER & 0.17 & -0.02 & 0.14 & 1.00 \\
\hline \multirow[t]{4}{*}{ Indonesia } & VWBASPREAD & 1.00 & & & \\
\hline & RETURN & -0.24 & 1.00 & & \\
\hline & VOLAT & 0.04 & 0.01 & 1.00 & \\
\hline & TURNOVER & -0.08 & 0.22 & 0.45 & \\
\hline \multirow[t]{4}{*}{ Korea } & VWBASPREAD & 1.00 & & & \\
\hline & RETURN & -0.29 & 1.00 & & \\
\hline & VOLAT & 0.08 & -0.04 & 1.00 & \\
\hline & TURNOVER & 0.06 & 0.21 & 0.28 & 1.00 \\
\hline \multirow[t]{4}{*}{ Philippines } & VWBASPREAD & 1.00 & & & \\
\hline & RETURN & -0.10 & 1.00 & & \\
\hline & VOLAT & 0.07 & -0.03 & 1.00 & \\
\hline & TURNOVER & -0.02 & 0.03 & 0.23 & 1.00 \\
\hline \multirow[t]{4}{*}{ South Africa } & VWBASPREAD & 1.00 & & & \\
\hline & RETURN & -0.13 & & & \\
\hline & VOLAT & 0.20 & 1.00 & 1.00 & \\
\hline & TURNOVER & 0.02 & 0.03 & 0.15 & 1.00 \\
\hline \multirow[t]{4}{*}{ Taiwan } & VWBASPREAD & 1.00 & & & \\
\hline & RETURN & -0.18 & 1.00 & & \\
\hline & VOLAT & -0.17 & 0.05 & 1.00 & \\
\hline & TURNOVER & -0.08 & 0.30 & 0.25 & 1.00 \\
\hline \multirow[t]{4}{*}{ Thailand } & VWBASPREAD & 1.00 & & & \\
\hline & RETURN & -0.19 & 1.00 & & \\
\hline & VOLAT & 0.12 & 0.00 & 1.00 & \\
\hline & TURNOVER & -0.01 & 0.23 & 0.38 & 1.00 \\
\hline
\end{tabular}

Panel B. Chi-square statistics from Granger causality tests. Null

hypothesis: Row variable do not Granger-cause column variable

\begin{tabular}{|l|r|r|r|r|}
\multicolumn{1}{l|}{ VWBASPREAD } & \multicolumn{1}{r}{ RETURN } & \multicolumn{1}{r|}{ VOLAT } & TURNOVER \\
\hline VWBASPREAD & & $\mathbf{6 . 8 3}$ & $\mathbf{6 . 1 1}$ & $\mathbf{7 . 6 0}$ \\
RETURN & $\mathbf{1 2 . 6 6}$ & & $\mathbf{5 6 . 9 2}$ & $\mathbf{1 6 . 1 3}$ \\
VOLAT & $\mathbf{1 4 . 4 5}$ & 3.11 & & $\mathbf{4 0 . 9 3}$ \\
TURNOVER & 0.05 & 2.75 & 0.70 & \\
\hline VWBASPREAD & & 2.73 & $\mathbf{6 . 4 2}$ & $\mathbf{8 . 1 1}$ \\
RETURN & $\mathbf{2 4 . 1 8}$ & & $\mathbf{2 4 . 2 3}$ & $\mathbf{1 8 . 2 2}$ \\
VOLAT & 2.44 & 2.89 & & $\mathbf{2 1 . 6 0}$ \\
TURNOVER & $\mathbf{9 . 8 4}$ & 0.26 & 5.49 & \\
\hline VWBASPREAD & & 2.70 & $\mathbf{1 6 . 3 2}$ & 4.17 \\
RETURN & $\mathbf{2 9 . 2 8}$ & & $\mathbf{2 0 . 0 3}$ & $\mathbf{9 2 . 5 5}$ \\
VOLAT & $\mathbf{2 4 . 4 7}$ & 4.69 & & $\mathbf{1 6 . 7 5}$ \\
TURNOVER & $\mathbf{1 6 . 2 0}$ & 1.35 & $\mathbf{6 . 0 8}$ & \\
\hline VWBASPREAD & & 1.27 & 0.62 & 0.88 \\
RETURN & 3.50 & & 0.19 & $\mathbf{1 0 . 1 2}$ \\
VOLAT & 0.42 & 1.14 & & 0.17 \\
TURNOVER & $\mathbf{5 . 3 2}$ & 0.21 & $\mathbf{8 . 4 5}$ & \\
\hline VWBASPREAD & & 1.69 & $\mathbf{4 0 . 5 2}$ & 3.80 \\
RETURN & 1.65 & & 3.57 & 1.31 \\
VOLAT & $\mathbf{3 4 . 5 2}$ & 1.49 & & $\mathbf{6 . 3 0}$ \\
TURNOVER & 2.47 & 0.25 & 2.10 & \\
\hline VWBASPREAD & & 2.08 & 4.41 & 4.87 \\
RETURN & $\mathbf{1 7 . 4 0}$ & & $\mathbf{2 7 . 6 4}$ & $\mathbf{4 5 . 0 7}$ \\
VOLAT & 4.28 & $\mathbf{1 1 . 5 6}$ & & $\mathbf{6 . 0 4}$ \\
TURNOVER & 3.91 & $\mathbf{7 . 3 2}$ & 2.77 & \\
\hline VWBASPREAD & & 4.47 & $\mathbf{1 0 . 8 8}$ & $\mathbf{7 . 0 2}$ \\
RETURN & $\mathbf{7 . 4 9}$ & & 1.76 & $\mathbf{9 2 . 3 4}$ \\
VOLAT & $\mathbf{1 1 . 0 1}$ & 3.44 & 2.49 & 4.75 \\
TURNOVER & & & & \\
\hline
\end{tabular}

The table presents the results of a 4-VAR model with daily endogenous variables VWBASPREAD, RETURN, VOLAT and TURNOVER. The 4-VAR is estimated with a constant, and 2 lags for all cases, except Philippines and South Africa with only one lag. Panel A presents the correlations between the contemporaneous innovations of each endogenous variable. Panel B presents the chi-square statistics for the pairwise Granger causality test.

VWBASPREAD: log of the value weighted average of the proportional quoted spread in the market, calculated from individual quotes for the day. Quotes from Bloomberg for all countries but Indonesia and South Africa that come from Datastream. Value weights from individual market capitalization from Datastream. Remaining market variables come mostly from Bloomberg, and complemented with Datastream as needed: RETURN: change on the log of the main market index. VOLAT: Absolute value of RETURN. TURNOVER, log of the market turnover estimated as Total trading value/ Total market capitalization . The variables were detrended and filtered out of deterministic trends as explained in section 4. Correlations and chi-squares significant at the 5\% level are indicated in bold. 


\section{Table VII Granger causality results for a 5 -VAR daily country model with liquidity and foreign trade}

Panel A . Correlations between VAR innovations

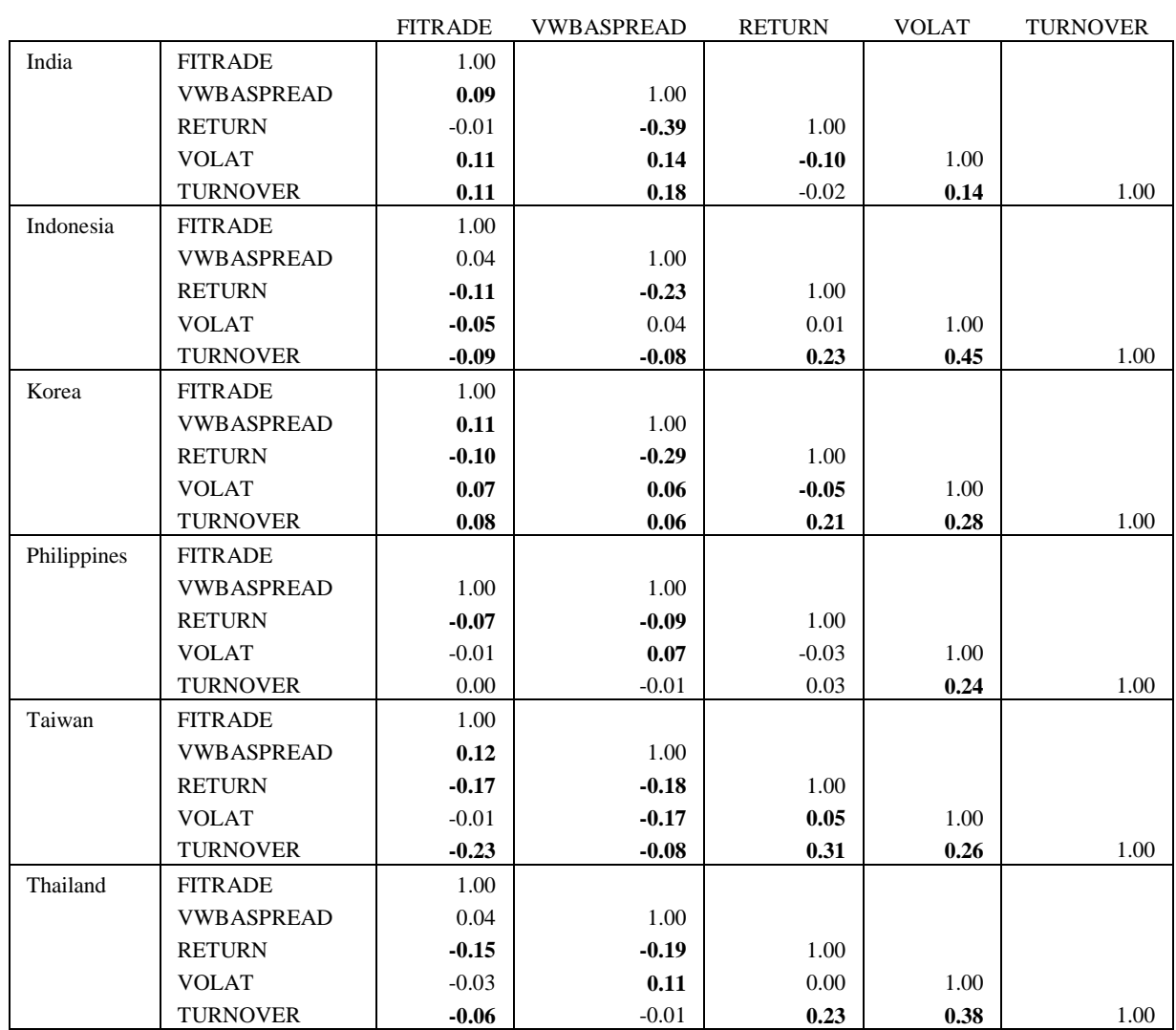

Panel B. Chi-square statistics from Granger causality tests. Null hypothesis: Row variable do not Granger-cause column variable

The table presents the results of a 5-VAR model with daily endogenous variables FITRADE, VWBASPREAD, RETURN, VOLAT and TURNOVER. The 5-VAR is estimated with a constant, and 2 lags for all cases, except Korea and Taiwan with three lags. Panel A presents the correlations between the contemporaneous innovations of each endogenous variable. Panel B presents the chi-square statistics for the pairwise Granger causality test. VWBASPREAD: log of the individual market capitalization from Datastream. Remaining market variables come mostly from Bloomberg, and complemented with Datastream as needed: RETURN: change on the log of the main market index. VOLAT: Absolute value of RETURN. TURNOVER, log of the market turnover estimated as Total trading value/ Total market capitalization. FITRADE: average proportion of the trading volume due to foreigners, calculated as: [Foreigners sales (LCU) +Foreign buys (LCU) ] /2/ Trading volume (LCU) . The variables were detrended and filtered out of deterministic trends as explained in section 4. Correlations and chi-squares significant at the 5\% level are indicated in bold. 
Table VIII. Granger causality results for a 5 -VAR daily country model with liquidity and foreign netbuy

Panel A . Correlations between VAR innovations

\begin{tabular}{|c|c|c|c|c|c|c|}
\hline \multirow{6}{*}{ India } & & FINETBUY & VWBASPREAD & RETURN & VOLAT & TURNOVER \\
\hline & FINETBUY & 1.00 & & & & \\
\hline & VWBASPREAD & -0.07 & 1.00 & & & \\
\hline & RETURN & 0.20 & -0.39 & 1.00 & & \\
\hline & VOLAT & 0.05 & 0.14 & -0.10 & 1.00 & \\
\hline & TURNOVER & 0.08 & 0.17 & -0.02 & 0.14 & 1.00 \\
\hline \multirow[t]{5}{*}{ Indonesia } & FINETBUY & 1.00 & & & & \\
\hline & VWBASPREAD & -0.07 & 1.00 & & & \\
\hline & RETURN & 0.23 & -0.23 & 1.00 & & \\
\hline & VOLAT & 0.05 & 0.04 & 0.01 & 1.00 & \\
\hline & TURNOVER & 0.26 & -0.08 & 0.22 & 0.45 & 1.00 \\
\hline \multirow[t]{5}{*}{ Korea } & FINETBUY & 1.00 & & & & \\
\hline & VWBASPREAD & -0.04 & 1.00 & & & \\
\hline & RETURN & 0.23 & -0.28 & 1.00 & & \\
\hline & VOLAT & -0.01 & 0.08 & -0.04 & 1.00 & \\
\hline & TURNOVER & 0.23 & 0.06 & 0.21 & 0.29 & 1.00 \\
\hline \multirow[t]{5}{*}{ Philippines } & FINETBUY & 1.00 & & & & \\
\hline & VWBASPREAD & -0.01 & 1.00 & & & \\
\hline & RETURN & 0.11 & -0.09 & 1.00 & & \\
\hline & VOLAT & 0.02 & 0.07 & -0.03 & 1.00 & \\
\hline & TURNOVER & 0.06 & -0.01 & 0.04 & 0.24 & 1.00 \\
\hline \multirow[t]{5}{*}{ South Africa } & FINETBUY & 1.00 & & & & \\
\hline & VWBASPREAD & -0.03 & 1.00 & & & \\
\hline & RETURN & -0.07 & -0.13 & 1.00 & & \\
\hline & VOLAT & -0.01 & 0.19 & 0.03 & 1.00 & \\
\hline & TURNOVER & 0.03 & 0.04 & 0.06 & 0.21 & 1.00 \\
\hline \multirow[t]{5}{*}{ Taiwan } & FINETBUY & 1.00 & & & & \\
\hline & VWBASPREAD & -0.06 & 1.00 & & & \\
\hline & RETURN & 0.33 & -0.18 & 1.00 & & \\
\hline & VOLAT & 0.02 & -0.17 & 0.05 & 1.00 & \\
\hline & TURNOVER & 0.19 & -0.08 & 0.31 & 0.26 & 1.00 \\
\hline \multirow[t]{5}{*}{ Thailand } & FINETBUY & 1.00 & & & & \\
\hline & VWBASPREAD & -0.06 & 1.00 & & & \\
\hline & RETURN & 0.32 & -0.19 & 1.00 & & \\
\hline & VOLAT & -0.04 & 0.12 & 0.00 & 1.00 & \\
\hline & TURNOVER & 0.06 & -0.01 & 0.23 & 0.38 & 1.00 \\
\hline
\end{tabular}

Panel B. Chi-square statistics from Granger causality tests. Null hypothesis: Row variable do not Granger-cause column variable

The table presents the results of a 5-VAR model with daily endogenous variables FINETBUY, VWBASPREAD, RETURN, VOLAT and TURNOVER. The 5-VAR is estimated with a constant, and 2 lags for all cases, except Taiwan with three lags. Panel A presents the correlations between the contemporaneous innovations of each endogenous variable. Panel B presents the chi-square statistics for the pairwise Granger causality test. VWBASPREAD: log of the value weighted averag of the proportional quoted spread in the market, calculated from individual quotes for the day. Quotes from Bloomberg for all countries but Indonesia and South Africa that come from Datastream. Value weights from individual market capitalization from Datastream. Remaining market variables come mostly from Bloomberg, and complemented with Datastream as needed: RETURN. change on the log of the main market index. VOLAT. Absolute value of RETURN. (FCU) - Foreign sales (LCU) / Matign

\begin{tabular}{|c|c|c|c|c|c|}
\hline & FINETBUY & VWBASPREAD & RETURN & VOLAT & TURNOVER \\
\hline FINETBUY & & 17.20 & 8.05 & 1.79 & 3.46 \\
\hline VWBASPREAD & 6.12 & & 8.90 & $\underline{5.15}$ & 8.78 \\
\hline RETURN & 29.94 & 16.30 & & $\overline{50.20}$ & 18.62 \\
\hline VOLAT & $\underline{5.55}$ & 15.18 & 2.68 & & 41.45 \\
\hline TURNOVER & 3.33 & 0.03 & 2.81 & 0.67 & \\
\hline FINETBUY & & 2.59 & 0.84 & 1.77 & 11.29 \\
\hline VWBASPREAD & 1.18 & & 2.69 & 6.34 & 8.54 \\
\hline RETURN & 54.06 & 25.77 & & 21.06 & 21.81 \\
\hline VOLAT & 5.48 & 2.25 & 2.87 & & 20.31 \\
\hline TURNOVER & $\overline{0.51}$ & 8.79 & 0.31 & 5.59 & \\
\hline FINETBUY & & 7.89 & 3.76 & 0.59 & 31.14 \\
\hline VWBASPREAD & 3.40 & & 3.03 & 16.46 & 4.86 \\
\hline RETURN & 142.90 & 21.48 & & 17.81 & $\overline{99.45}$ \\
\hline VOLAT & 0.31 & 23.90 & $\underline{5.11}$ & & 15.86 \\
\hline TURNOVER & 0.95 & 13.24 & 1.91 & 5.88 & \\
\hline FINETBUY & & 0.28 & 4.76 & 5.24 & 1.59 \\
\hline VWBASPREAD & 1.07 & & $\overline{4.31}$ & $\overline{1.29}$ & 1.31 \\
\hline RETURN & 29.78 & $\underline{5.38}$ & & 2.89 & 13.62 \\
\hline VOLAT & 0.14 & 2.99 & 1.37 & & 0.25 \\
\hline TURNOVER & 1.31 & 5.35 & 0.27 & 8.50 & \\
\hline FINETBUY & & 2.83 & 2.89 & 0.05 & 2.09 \\
\hline VWBASPREAD & 2.75 & & 1.33 & 37.93 & 2.38 \\
\hline RETURN & 2.00 & 3.99 & & 9.90 & 1.80 \\
\hline VOLAT & 7.07 & 26.63 & 5.03 & & 2.08 \\
\hline TURNOVER & 0.81 & 3.34 & 0.92 & 2.19 & \\
\hline FINETBUY & & 5.53 & 35.24 & 13.77 & 4.14 \\
\hline VWBASPREAD & 3.52 & & 4.12 & 4.28 & 4.65 \\
\hline RETURN & 50.49 & 11.99 & & 16.13 & 51.66 \\
\hline VOLAT & 4.58 & 4.95 & 10.78 & & 22.15 \\
\hline TURNOVER & 7.89 & 1.47 & $\underline{6.89}$ & 3.95 & \\
\hline FINETBUY & & 0.08 & 11.31 & 0.53 & 0.18 \\
\hline VWBASPREAD & 4.52 & & 4.53 & 11.05 & 7.04 \\
\hline RETURN & 167.98 & 7.03 & & 2.27 & 87.14 \\
\hline VOLAT & 1.69 & 8.66 & 1.29 & & 4.57 \\
\hline TURNOVER & 9.92 & 10.33 & 3.26 & 2.01 & \\
\hline
\end{tabular}

TURNOVER, log of the market turnover estimated as Total trading value/ Total market capitalization. FNNETBUY: Total Net buys by foreigners in the market, calculated as: [Foreigners buys (LCU) 
